Published in final edited form as:

Cochrane Database Syst Rev. ; (4): CD004371. doi:10.1002/14651858.CD004371.pub2.

\title{
Interventions to improve adherence to lipid lowering medication
}

\author{
Angela Schedlbauer ${ }^{1}$, Knut Schroeder $^{2}$, Tim Peters ${ }^{3}$, and Tom Fahey ${ }^{4}$ \\ ${ }^{1}$ Division of Primary Care, School of Community Health Studies, Nottingham, UK ${ }^{2}$ Academic Unit \\ of Primary Health Care, Department of Community Based Medicine, Cotham Hill, UK ${ }^{3}$ Academic \\ Unit of Primary Health Care, Department of Community Based Medicine, University of Bristol, \\ Bristol, UK ${ }^{4}$ Department of Family Medicine and General Practice, Royal College of Surgeons in \\ Ireland Medical School, Dublin, Ireland
}

\begin{abstract}
Background-Lipid lowering drugs are still widely underused, despite compelling evidence about their effectiveness in the treatment and prevention of cardiovascular disease. Poor patient adherence to medication regimen is a major factor in the lack of success in treating hyperlipidaemia. In this review we focus on interventions, which encourage patients at risk of heart disease or stroke to take lipid lowering medication regularly.
\end{abstract}

Objectives-To assess the effect of interventions aiming at improved adherence to lipid lowering drugs, focusing on measures of adherence and clinical outcomes.

Search strategy-We searched the Cochrane Central Register of Controlled Trials (CENTRAL), MEDLINE, EMBASE, PsycInfo and CINAHL. Date of most recent search was in February 2003. No language restrictions were applied.

Copyright @ 2009 The Cochrane Collaboration. Published by John Wiley \& Sons, Ltd

Contact address: Angela Schedlbauer, Division of Primary Care, School of Community Health Studies, University of Nottingham, Nottingham, NG7 2RD, UK. angela.schedlbauer@nottingham.ac.uk.

Editorial group: Cochrane Heart Group.

Publication status and date: Edited (no change to conclusions), published in Issue 1, 2009.

Review content assessed as up-to-date: 31 July 2004.

CONTRIBUTIONS OF AUTHORS

Angela Schedlbauer obtained funding for the review. Designed, coordinated and wrote the review. Was responsible for data collection and interpreting of the data.

Knut Schroeder conceived the review and was involved with the review design and writing of the protocol. Provided general advice on the review and contributed to the screening of search results, data extraction, interpretation of data. Commented on successive drafts of the manuscript

Tom Fahey was involved with developing the protocol, interpreting the data, commenting on the included studies and successive drafts of the manuscript of the review.

Tim Peters was involved with the analysis of data, provided general advice on interpreting the data and commented on successive drafts of the manuscript.

DECLARATIONS OF INTEREST

None known

NOTES The Peninsula Technology Assessment Group (PenTAG) at Peninsula Medical School, Exeter, UK and the Cochrane Heart Group have been awarded a 3-year grant from the National Institute for Health Research to update existing Cochrane systematic reviews relevant to public health, primary care and rehabilitation.

This review is scheduled to be updated in the first year of the program. Publication of the updated review is anticipated by issue 2, 2009 at the latest. 
Selection criteria-Randomised controlled trials of adherence-enhancing interventions to lipid lowering medication in adults for both primary and secondary prevention of cardiovascular disease in an ambulatory setting.

Data collection and analysis-Two reviewers extracted data independently and assessed studies according to criteria outlined by the Cochrane Reviewers' Handbook.

Main results-The eight studies found contained data on 5943 patients. Interventions could be stratified into four categories: 1. simplification of drug regimen, 2. patient information/education, 3. intensified patient care such as reminding and 4. complex behavioural interventions such as group sessions. Change in adherence ranged from $-3 \%$ to $25 \%$ (decrease in adherence by $3 \%$ to increase in adherence by 25\%). Three studies reported significantly improved adherence through simplification of drug regimen (category 1), improved patient information/education (category 2) and reminding (category 3 ). The fact that the successful interventions were evenly spread across the categories, does not suggest any advantage of one particular type of intervention. The methodological and analytical quality was generally low and results have to be considered with caution. Combining data was not appropriate due to the substantial heterogeneity between included randomised controlled trials (RCTs).

Authors' conclusions-At this stage, no specific intervention aimed at improving adherence to lipid lowering drugs can be recommended. The lack of a gold standard method of measuring adherence is one major barrier in adherence research. More reliable data might be achieved by newer methods of measurement, more consistency in adherence assessment and longer duration of follow-up. Increased patient-centredness with emphasis on the patient's perspective and shareddecision-making might lead to more conclusive answers when searching for tools to encourage patients to take lipid lowering medication.

\section{Medical Subject Headings (MeSH)}

*Patient Compliance; Antilipemic Agents [*therapeutic use]; Cardiovascular Diseases [prevention $\&$ control]; Randomized Controlled Trials as Topic

\section{MeSH check words}

Humans

\section{BACKGROUND}

Despite compelling evidence about the effectiveness of lipid lowering drugs and the introduction of clear guidelines in recent years, lipid lowering therapy is still underused. According to a cross-sectional study, target cholesterol concentrations are only achieved in fewer than 50 per cent of people receiving treatment (Primatesta 2000). Lack of adherence and high discontinuation rates have been shown to be important factors in failing treatment when looking at both high cholesterol levels (Maenpaa 1991) and morbidity in terms of recurrent myocardial infarction (Wei 2002).

Hyperlipidaemia is an important risk factor for coronary heart disease and causes about onethird of cardiovascular disease (CVD) worldwide (WHO 2002). Elevated serum 
concentrations of total cholesterol (TC), low-density-lipoprotein (LDL) and total triglycerides (TRG) are associated with an increased coronary heart disease (CHD) risk, whereas high-density-lipoproteins (HDL) or a low TC/HDL ratio appear to be protective. Treatment of hyperlipidaemia with lipid lowering medication (hypolipidaemics) include statins, fibrates or anion-exchange resins. Statins in particular have been shown to be effective in preventing CHD events and in reducing overall mortality in large randomised controlled trials (Athyros 2002a; Downs 1998; 4S 1994; MRC/BHF 2002; Sacks 1996; Shepherd 1995; LIPID 1998). Fibrates and anion-exchange resins also achieved reduction in CHD events, but showed a non-significant increase in non-coronary mortality (Downs 1998; SIGN 1999). Statins are therefore recommended as first line therapy, whereas fibrates and anion-exchange resins can be considered as second line therapy, also in combination with statins (Downs 1998; SIGN 1999).

Recommendations about drug treatment vary from country to country. In the UK, treatment with statins is indicated in patients with atherosclerotic disease to reduce further ischaemic events for secondary prevention. For primary prevention, medication is recommended in asymptomatic patients with a total serum-cholesterol of $5 \mathrm{mmol} / \mathrm{l}(194 \mathrm{mg} / \mathrm{dl})$ or greater, whose risk of developing CHD over 10 years is above 30 per cent (DOH 2000). The aim of current treatment targets is to decrease total serum-cholesterol concentrations to below $5 \mathrm{mmol} / \mathrm{l}$ or by 20 to 25 per cent, whichever results in the lower concentration (DOH 2000). US guidelines recommend drug treatment to anyone with an LDL over $100 \mathrm{mg} / \mathrm{dl}$ (2.6mmol/l), whose CHD risk over 10 years is 20 per cent or above (ATP III). A combination of statins, blood pressure lowering drugs and low dose aspirin is recommended by The World Health Report 2002 for secondary prevention of CVD, as this could cut death rates and disability rates from CVD by more than 50 percent (WHO Report 2002). In England, 7000 myocardial infarctions and 2500 strokes could be avoided each year if individuals at high risk, who are not taking medication, received lipid lowering treatment (Primatesta 2000). These figures show the impact of lipid lowering drugs on public health and thus the importance of their acceptance by patients.

Adherence is defined as the extent as to which patients take medication as prescribed. Since the landmark publication by Sacket et al in 1976 (Sackett 1976), it has been the focus of research over the last three decades which was summarised in a review by Vermeire (Vermeire 2001). Adherence can be intentional and non-intentional and is determined by a variety of factors such as lack of knowledge, denial, adverse effects, poor memory, adverse attitudes to treatment and others. Reliable indicators of adherent behaviour have not been found to date and demographic factors such as age, sex or social class have been shown to be poor predictors of adherence (Vermeire 2001). The importance of the patient's agreement (Lewis 2003) and the significance of the patient's role within the doctor-patient relationship have been emphasised (RPS 1997). As a consequence, adherence and concordance have been used in recent years as more patient-centred synonyms for compliance (Mullen 1997). The treatment of hyperlipidaemia, a symptomless condition, aims at reducing CHD risk and has no immediate effect on patients' wellbeing. In addition to adverse effects caused by medical treatment, this might make it particularly hard for patients to stick to a long-term regimen. It has been difficult to identify the scope of the problem, as adherence rates from hyperlipidaemia trials show considerable variation ranging from thirty-seven to eighty per 
cent, depending on factors such as study population, background morbidity, classes of drugs, duration of follow-up and adherence measuring methods (Tsuyuki 2001). Epidemiological data show that only one in four patients continued taking lipid lowering medication longterm: Twenty-five per cent of elderly patients maintained good adherence to a statin after five years in a cohort study enrolling 34,501 patients (Benner 2002). Not surprisingly, primary prevention trials appear to have higher discontinuation rates than secondary prevention trials, which indicates a relationship between adherence and awareness of illness (Tsuyuki 2001). This was confirmed in a recent population-based study involving elderly people, where sixty per cent of patients prescribed a statin for acute coronary syndrome gave up treatment within two years, compared to seventy-five per cent without coronary disease (Jackevicius 2002).

Three systematic reviews published in the Cochrane Library looked at adherence-enhancing interventions. Haynes et al presented methods that were effective in improving adherence to prescribed medication. They were mostly complex, including combinations of more convenient care, information, reminders, self-monitoring, reinforcement,counselling, family therapy and other forms of supervision or attention (Haynes 2004). Even the most effective intervention did not lead to large improvements in adherence and treatment outcomes. The review included one study looking at lipid lowering drugs, which reported improved medication adherence by reducing the dosing frequency (Brown 1997). Schroeder and colleagues focused on medication for controlling blood pressure and reported enhanced adherence by reducing the number of daily doses. They suggested innovative approaches to be introduced in the context of further RCTs, considering motivational strategies and complex interventions in particular (Schroeder 2004b). Another review found educational and supportive counselling to be the only available intervention to increase adherence to highly active antiretroviral therapy for HIV/AIDS (Haddad 2000).

In this review, we focus on interventions designed to help people take their lipid lowering medication in an ambulatory care setting.

\section{OBJECTIVES}

To determine the effect of adherence-enhancing interventions on adherence to prescribed, self-administered lipid lowering medication and on clinical outcomes.

\section{METHODS}

\section{Criteria for considering studies for this review}

Types of studies-Randomised controlled trials (RCTs) of parallel group or crossover design, that used individual or cluster randomisation.

Types of participants-All adults (over 18 years of age) who were prescribed lipid lowering medication for primary or secondary prevention of cardiovascular disease in ambulatory care settings. 
Types of interventions-Interventions of any type intended to increase adherence to self-administered lipid lowering medication versus 'usual care' or 'no intervention'.

This will include, but is not exclusive to interventions such as:

(1) Simplification of drug regimen;

(2) Patient education and information;

(3) Intensified patient care (increased follow-up, sending out reminders, etc.);

(4) Complex behavioural approach (increasing motivation by arranging group sessions, giving out rewards, etc.);

(5) Decision Support Systems;

(6) Administrative improvements (audit, documentation, computers).

Types of outcome measures-Measuring adherence continues to be widely variable and remains controversial. Four categories of adherence assessment can be identified and have been included:

(1) Indirect measures of adherence (e.g. pill count, prescription refill rate, electronic monitoring);

(2) Subjective measures of adherence (e.g. patients' self-report in diaries, interviews);

(3) Direct measures of adherence (tracer substances in blood or urine);

(4) Physiological indicators (e.g. total cholesterol, LDL, HDL, apolipoproteins, triglycerides, and respective ratios);

(5) Health outcome indications (e.g. quality of life, morbidity, mortality);

(6) Adverse effects.

In the literature, physiological indicators, health outcomes and adverse effects are used as proxy measures for adherence (see table of excluded studies). Studies are only included if these are reported in association with adherence outcomes.

\section{Search methods for identification of studies}

We searched the Cochrane Central Register of Controlled Trials (CENTRAL) on The Cochrane Library, MEDLINE, EMBASE, PsycINFO and CINAHL. The search included ongoing trials (e.g. UK National Research Register and Trials Central). All languages were included. Searches were conducted in:

- CENTRAL on Issue 1, 2003 (Table 1);

- MEDLINE (from January 2000 to February 2003);

- EMBASE with an appropriate RCT filter (Lefebvre 1996) from January 1998 to February 2003 (Table 2);

- CINAHL from January 1982 to February 2003 (Table 3); 
- PsychINFO from 1972 to February 2003 (Table 4).

CENTRAL incorporates all controlled trials from EMBASE and MEDLINE with exception of the most recent years. To avoid duplicates, the search in these two databases only covered the years in which controlled trials would not have been included in CENTRAL.

In addition, we searched reference lists of retrieved papers and contacted 8 study authors and experts in the field for additional information on further published and unpublished studies.

Specific search terms-The following terms were used to search MEDLINE in February 2003, with the addition of a filter for randomised controlled trials (Dickersin 1994). These were adapted appropriately for other databases (See Table 1, Table 2, Table 3 and Table 4).

\section{1. $\operatorname{exp~HYPERLIPIDEMIA/~}$}

2. exp Antilipemic Agents/

3. hypercholesterol\$.tw.

4. hyperlipid\$.tw.

5. statin $\$ . t w$.

6. antilipid\$.tw.

7. hyperlip?emia.tw.

8. dyslip?emia.tw.

9. lipid lowering.tw.

10. or/1-9

11. exp Patient Compliance/

12. Treatment Refusal/

13. Patient Dropouts/

14. exp Attitude to Health/

15. Patient Satisfaction/

16. (adher\$ or non-adherence $\$$ or nonadherence\$).tw.

17. (compliance $\$$ or noncompliance $\$$ or non-compliance $\$$ ).tw.

18. (refusal or refuse $\$$ ).tw.

19. (improv $\$$ adj5 (follow-up or follow up)).tw.

20. (dropout $\$$ or drop-out $\$$ or drop out\$).tw.

21. (patient $\$$ adj3 (attitude $\$$ or acceptance $\$$ or satisfaction)).tw.

22. (treatment $\$$ adj3 (stop\$ or abandon\$)).tw.

23. or/11-22 
24. exp Counseling/

25. patient care/

26. Case Management/

27. Health Behavior/

28. exp Patient Education/

29. exp Behavior Therapy/

30. (behavi $\$$ adj3 (modif $\$$ or therap\$ or adjust\$)).tw.

31. Patient Care Planning/

32. Nurse Practitioners/

33. Pharmacists/

34. counsel\$.tw.

35. patient education $\$ . t w$.

36. (patient $\$$ adj 3 educat $\$$ ).tw.

37. ((nurse $\$$ or pharmac $\$$ ) adj 3 (led $\$$ or manage $\$$ or program $\$$ or based)).tw.

38. or $/ 24-37$

39. 23 or 38

40. 10 and 39

\section{Data collection and analysis}

Study selection-Two reviewers selected studies independently by assessing titles and abstracts. Full text articles of potential relevance were obtained. Following this initial screening, trials were selected by applying predetermined inclusion criteria. A trial was included if it met all our inclusion criteria. Disagreements were discussed and resolved between the reviewers. A reference management system (Reference Manager) was used to identify and extract duplicate studies.

Study evaluation-Quality assessment was performed using the four main sources of systematic bias in trials: selection bias, performance bias, attrition bias and detection bias. Guidelines about quality assessment of the Cochrane Reviewers' Handbook were followed (Alderson 2004). Allocation concealment, blinding to assessment of outcomes, losses to follow up and adequacy of control were coded as adequate (A), unclear (B), inadequate (C) or not used (D). Any disagreements were resolved by discussion involving a third party if necessary. Records were kept in form of a 'Quality of reporting of meta-analyses, or QUOROM, statement (Moher 1999). We also took into consideration the method used to measure adherence, as some methods are more likely to be biased than others (see under study description). 
Data extraction-Study outcome data were extracted using pre-defined data collection forms that had been developed for this review. The form was developed and piloted on a random sample of three studies and refined appropriately. Data were extracted by two reviewers independently. We contacted 6 study authors of original studies for clarification of details or further information, of whom 5 responded.

Data analysis-Heterogeneity between studies detected in various areas (adherence measurement, patient characteristics, duration, interventions used) did not allow pooling of the data. We attempted to group studies according to the type of interventions (see below) and to compare the outcomes independently from each other. We also attempted to recalculate outcomes where the reported data allowed this, using the Stata 8.0 statistical software package (Stata).

\section{RESULTS}

\section{Description of studies}

See: Characteristics of included studies; Characteristics of excluded studies; Characteristics of ongoing studies.

The search contained 2380 articles, of which 2292 were excluded by assessing titles and abstracts (no RCT design, not an ambulatory setting, not concerned with lipidaemia, or not concerned with adherence). We retrieved 88 full text articles and excluded 80 trials ( 3 were not concerned with lipidaemia at all, 37 were not designed as RCTs, 32 did not focus on interventions to improve adherence and 8 did not have adherence as an outcome). 8 studies met all the inclusion criteria and were included in the review, the combined patient number being 5943. The study size varied from 30 to 4548 patients. The trials showed a great variation in type of participants, setting, medication, intervention used and outcomes measured, which are described in more detail in the Characteristics of Included Studies Table.

Interventions-Stratification of interventions into groups was performed on pragmatic grounds as generally accepted categories do not exist. Four main groups were identified:

(1) Simplification of drug regimen (Brown 1997; Sweeney 1991);

(2) Patient education and information (Poston 1998; Powell 1995;

(3) Intensified patient care: Reminders via mail and telephone (Faulkner 2000; Guthrie 2001; Schectman 1994);

(4) Complex behavioural approach: group sessions (Marquez 1998).

Medication-The lipid lowering medication used to treat hyperlipidaemia in the majority of trials were Statins/HMG-CoA reductase inhibitors ( 5 trials), followed by anion-exchange resins/bile acid sequestrants ( 3 trials) and niacin/nicotinic acid ( 2 trials). Two trials used combined medication regimen. Drug therapy was most commonly started after study allocation; only two studies included patients who were already taking lipid lowering medication (Poston 1998; Powell 1995). 
Cardiovascular risk-Three trials included in this review enrolled only participants with pre-existing cardiovascular pathology or increased cardiovascular risk (Brown 1997; Faulkner 2000; Guthrie 2001), two included healthy patients with high cholesterol levels (Marquez 1998; Sweeney 1991) and another three included patients on medication for both primary and secondary prevention (Poston 1998; Powell 1995; Schectman 1994).

Settings-Two of the included trials took place in primary care (Guthrie 2001; Marquez 1998), two in secondary care (Brown 1997; Faulkner 2000) and one in both (Sweeney 1991). Other settings were local pharmacies (Poston 1998), Health Maintenance Organisations (Powell 1995) and Veteran Affairs Medical Centres (Schectman 1994). The geographical setting of most studies was the USA. One study took place in Canada and one in Spain.

Follow-up-Follow-up time was generally short, ranging from 2 to 24 months. Most studies achieved their endpoint outcomes at 3-9 months (see characteristics of included studies).

Outcome measures-The methods used to measure adherence were self-report, prescription refill rate and pill count. Self-report was used in one study asking patients if they had taken their medication as prescribed and how many doses were missed in the past 7 days (Guthrie 2001). Prescription refill rates were used by 4 studies, where refill information was obtained from pharmacies (Faulkner 2000; Poston 1998; Powell 1995; Schectman 1994). Pill counting was performed in 4 trials (Brown 1997; Faulkner 2000; Marquez 1998; Sweeney 1991). Counting pills is vulnerable to patient manipulation, and one author attempted to increase reliability of this method by performing unexpected visits to patients' homes for surprise pill counts (Marquez 1998). In another study pills were not counted in patients' view in order to avoid influencing patients' subsequent adherent behaviour (Faulkner 2000). Some authors used more than one of the above methods to measure adherence at different stages in their trials, which made comparison between trials even more difficult.

Several studies applied thresholds to define compliant behaviour i.e. proportion of patients taking more than $80 \%$ of the prescribed medication. This was considered a less valid description of compliant behaviour compared to reporting percentages of mean compliance and was therefore not reported in the tables. Discontinuation rates, frequently used as a proxy measure for adherence, were only reported in one study (Schectman 1994).

Serum lipids consisting of total cholesterol (TC), HDL, LDL and triglycerides (TRG) are physiological indicators of patient compliance and were only reported in 4 out of 8 trials (Brown 1997; Faulkner 2000; Marquez 1998; Sweeney 1991). Some trials began with a "start-up" phase where patients were either taking medication (Brown 1997) or following a diet (Sweeney 1991) before baseline blood samples were taken. Other trials took baseline blood samples immediately after recruitment.

Other reported outcome measures included side-effects experienced and reasons for noncompliance (Brown 1997, Faulkner 2000, Guthrie 2001; Marquez 1998; Schectman 1994; 
Sweeney 1991). None of the studies provided data on morbidity or mortality as additional outcome measures.

\section{Risk of bias in included studies}

The four main sources of systematic bias, selection bias, performance bias, attrition bias and detection bias were all considered in the process of study assessment, as recommended by the Cochrane Reviewers' Handbook (Alderson 2004). An overall assessment of the studies was performed by categorising them into low risk of bias (if all of the above criteria were met), moderate risk of bias (one or more criteria only partly met) and high risk of bias (one or more criteria not met). Few of the reported studies provided sufficient details to replicate the methodology used to avoid bias. None of the trials met all the criteria. Only two trials were categorised as having a moderate risk of bias (Faulkner 2000; Marquez 1998). The remaining studies were deemed to have moderate to high risk of bias, given that they did not meet one or more criteria.

Blinding patients to the intervention they were receiving was not possible in this particular setting. This inevitably raises the risk of bias. Blinding of the health carer/doctor, in order to avoid systematic differences in the care provided (performance bias), is in principle possible. It was attempted in two trials, where General Practitioners were blinded to patients' group allocation in order to assure the same provision of care to both intervention and control group (Faulkner 2000; Marquez 1998). Although this is the approach of choice it has its limitations as it is vulnerable to disclosure by patients.

More than half of the studies failed to provide standard deviations (SD) or standard errors (SE), which made recalculation of the results impossible.

\section{Effects of interventions}

Types of interventions-The trials of this review aimed at increasing adherence by applying interventions as followed:

Simplification of drug regimen: Simplifying drug regimen was attempted in two studies. Reducing medication intake from four times to twice daily improved mean medication intake by $11 \%$ (96\% in the intervention group (IVG) versus $85 \%$ in the control group (CG), p-value equals 0.01 (Brown 1997)). Drug modification by administering Colestyramine bars instead of powder to make intake easier decreased the adherence rate non significantly (91.8\% in IVG versus 94.8\% in CG, p greater than 0.05 (Sweeney 1991)). Patient preference and side effect profile was improved with twice daily intake (see the Characteristics of Included Studies Table).

Patient information and education: Pharmacist mediated information and postal back-ups successfully improved adherence in one trial (Poston 1998): videotapes, booklets and newspapers handed out by the local pharmacist followed by educational newsletters sent via post increased the adherence by $13 \%$ (92\% in IVG versus $79 \%$ in CG, p equals 0.005 ). This applied only to the subgroup of patients newly prescribed statin treatment, but not to patients 
on long term statin therapy (92\% versus $91 \%$, p reported as non-significant, but this was not based on a correct interaction test).

Another study attempted to increase information and education by sending out videotapes to members of a Health Maintenance Organisation, who were known to have a pharmacy claim for statins (Powell 1995). This less personal approach increased adherence rates only slightly (73\% in IVG versus $70 \%$ in CG, p greater than 0.05 ).

Intensified patient care - reminding: Reinforcement and reminding via telephone and postal back-ups were the interventions of interest in three studies. Weekly phone calls were reported as improving adherence in the IVG and adherence to statins judged by prescription refill was improved by $24 \%$ (63\% in IVG versus $39 \%$ in CG, p-value reported as less than 0.05)(Faulkner 2000).

Telephone and postal reminders in the remaining studies did not result in any significant improvement (79.7\% in IVG versus $77.4 \%$ in CG, p-value reported as non significant) (Guthrie 2001) and 88\% in IVG versus $82 \%$ in CG, p equals 0.32 (Schectman 1994)).

Complex behavioural approach - group sessions: Only one trial used a group behavioural approach, where participants attended small group training (Marquez 1998). This resulted in a moderately improved adherence in the intervention group of $4.7 \%$, which was not significant ( $88.5 \%$ in IVG versus $83.8 \%$ in $\mathrm{CG}$, p greater than 0.05 ).

Pooling of the results-Heterogeneity is present in many areas such as background morbidity, hyperlipidaemic treatment, assessment of adherence, duration of follow-up and is indicated by the wide range of adherence levels in the control groups of the studies from $23 \%$ to $94 \%$. Combining the data therefore did not seem appropriate.

Different classes of lipid lowering medication-No particular class of medication seemed to obtain generally higher adherence than others when simply comparing the adherence rates in the control arms of the trials. Adherence rates to medication with statins varied from $39 \%$ to $90 \%$, with resins/bile acid sequestrants from $23 \%$ to $95 \%$ and with niacin from $84 \%$ to $85 \%$ (see characteristics of included studies).

Adherence and cholesterol-Serum cholesterol can be considered as an important marker of adherence to lipid lowering medication, but was only reported in four studies included in this review. In one RCT, a significant increase in adherence resulted in decreased serum cholesterol levels (Brown 1997). Other trials showed non significant changes of both adherence and serum cholesterol (Marquez 1998; Sweeney 1991). Faulkner et al reported an inverse relationship involving an increase in adherence with a decrease in serum levels, but the results were not confirmed by recalculation (see under characteristics of included studies in the table section).

Adherence and discontinuation rates-Discontinuation rates in addition to adherence rates were only reported in one study (Schectman 1994). The differences between IVG and 
CG were non significant for each parameter, therefore further statements about the relationship between the two measures cannot be made.

Additional studies-We found two other studies of relevance. One looked at the effect of information leaflets (Bruckert 1999), but data were never published as no effect on patient compliance had been found. Another study looking at complex interventions (pharmacist compliance feedback plus electronic and educational reminders) is pending final data analysis by Eric de Klerk and was not included in this review (see under characteristics of ongoing studies).

Summary-Three studies reported a significantly improved adherence in the intervention groups compared to the control groups. These studies were evenly spread across the groups, suggesting no advantage of one particular type of intervention. None of these studies provided standard deviations or standard errors and attempts to retrieve data from the authors were not successful (see characteristics of included studies). Subgroup analysis, cluster randomised and crossover designs were used without applying relevant statistical analysis (Brown 1997; Poston 1998) and hence results have to be considered with caution.

A combined effect on both adherence and serum lipids was only found in one study, where simplified drug regimen significantly decreased the mean total serum-cholesterol by 14 $\mathrm{mg} / \mathrm{dl}$, mean LDL by $13 \mathrm{mg} / \mathrm{dl}$ and LDL/HDL ratio by 0.17 (Brown 1997). Group behavioural approach reported a considerable and significant decrease in triglycerides of 30 mg/dl (Marquez 1998). Bar versus powder colestyramine comparison showed a nonsignificant difference between groups (Sweeney 1991). Faulkner et al reported a significant decrease in total serum cholesterol, LDL and triglycerides, but recalculation did not confirm these results. Outcomes obtained at the endpoint of each trial are shown in more detail in the Characteristics of Included Studies Table.

\section{DISCUSSION}

Findings

The majority of studies did not increase adherence significantly by informing, reminding and motivating patients. Particular types of interventions did not seem to be more effective than others. It is emphasised that adherence rates were very variable, which makes comparison between trials difficult.

\section{Limitations of this review}

Measuring adherence-A variety of measures for adherence have been used. In this review, we only included trials reporting levels of adherence in terms of adherence rates. Studies using proxy measures for adherence such as discontinuation rates, adverse effects or physiological indicators do exist, but the relationship between those measures and levels of adherence remains unclear.

Comparing adherence levels between trials-Heterogeneity between trials makes direct comparison and pooling of the data inappropriate. Even important factors, such as the class of medication used, did not influence adherence rates as one would have expected. In 
this review, treatment with statins were not associated with higher adherence levels. This was surprising, considering that adherence to statins in general is thought to be higher than to niacin or resins due to fewer side effects (Avorn 1998; Eriksson 1998; Tsuyuki 2001). It indicates that the class of medication is only one of many factors affecting adherence and highlights the difficulty of comparing adherence rates between trials.

Underestimating the treatment effect-The difficulties in measuring adherent behaviour accurately and reliably is one of the main limitations of this review. An agreement on the 'gold standard' does not exist and the current reality in adherence research is the coexistence of different methods. Refill-records, patient self-report and pill count have been shown to overestimate adherence when compared to newer methods such as electronic monitoring of pill use or chemical markers (Maenpaa 1987; Roter 1998; Straka 1997; Urquhart 1994). The older methods used in the trials of this review may in part explain the high adherence levels in both intervention and control groups. If starting levels of adherence are high, it may reduce the effect sizes and lead to an underestimation of the intervention effect. This is known as a 'ceiling effect' (Dolan 1985).

Activities to follow up adherence might have a similar effect: phone calls or interviews to assess patient behaviour might act as an unintended intervention and increase adherence rates generally.

Methodological and analytical weaknesses-The quality of the studies in this review was generally low. Investigators assessing adherence in trials were often not blinded towards the interventions patients received and risk of bias was high in the majority of studies. The presentation of statistical analyses often omitted crucial details, so that the results could not be verified. When sufficient information was given, results were at times not consistent with our own calculations.

The analysis of covariance method when comparing serum lipid levels between groups was only applied by one study (Sweeney 1991). It takes into account the different baseline values in intervention and control group leading to more reliable results than is obtained by just comparing the mean endpoint values of each group. The baseline value was taken into consideration by another trial, comparing the proportional change from baseline in both groups (Faulkner 2000). The remaining trials compared endpoints only and did not adjust for baseline differences between intervention and control group at follow-up.

Study design-Results of crossover designs analysed in the same way as parallel group trials have to be considered with caution, as results of intervention and control groups are treated as if they came from an independent group of patients, which is clearly not the case (Clarke 2002). Poorly analysed cluster randomised trials are likely to over-estimate the statistical significance of the treatment effect, as observations in one cluster tend to be more similar to each other than to individuals of the rest of the sample. As a result standard errors and p-values may be too small and confidence intervals may be too narrow. Similarly, subgroup analysis should not be performed by just analysing the intervention effect in both subgroups, but should apply appropriate statistical tests for interaction (Assmann 2000). 
Significance and size of the intervention effect are therefore questionable in the crossover (Brown 1997) and cluster randomised trials (Poston 1998) included in this review.

\section{AUTHORS' CONCLUSIONS}

\section{Implications for practice}

Despite efforts to increase the use of lipid lowering medication and despite the fact that poor adherence to medication is common, randomised controlled trials in this area are very limited in both number and quality. At this stage, no adherence-enhancing intervention can be recommended in clinical practice.

\section{Implications for research}

The majority of interventions described in this review only focus on one or two aspects of adherence. The phenomenon of adherence is complex and it would seem reasonable for interventions to address this complexity with a more patient-centred approach (Schroeder 2004a). It has been stated that patients' beliefs and preferences need to be acknowledged more, being one of the most prevalent influences on medicine taking (RPS 1997). A combination of strategies including information, reminding, adherence reinforcement and emphasis on the patient's perspective might lead to more conclusive answers in further research.

The lack of a valid method for measuring adherence remains another obstacle to high quality research. Electronic monitoring could help to provide more detailed and reliable results in the pattern of adherence.

Other important aspects for further RCTs are long-term follow up, combination of adherence and serum lipid records, rigorous methodology, sufficient power and, eventually, the inclusion of economic analyses.

\section{Acknowledgments}

We would like to thank the South West Deanery and the Academic Unit of Primary Health Care in Bristol for the funding of the research fellowship, which made this review possible.

We would also like to thank the Cochrane Heart Group (Tess Moore and Kath Wornell) for the support they gave, and Margaret Burke in particular for her great help with the literature. We are grateful to Alan Montgomery for the support he gave us with statistical analyses and Stata.

Thank you to the authors of the original studies (B.G. Brown, E. Bruckert, M. Faulkner, E. de Klerk, E. Lesaffre, E. Marquez-Contreras) for their clarification and comments.

\section{SOURCES OF SUPPORT}

\section{Internal sources}

- $\quad$ Academic Unit of Primary Health Care, University of Bristol, UK.

- $\quad$ South West Deanery, Bristol, UK.

- $\quad$ Tayside Centre for General Practice, University of Dundee, UK.

\section{External sources}

- $\quad$ No sources of support supplied 


\section{CHARACTERISTICS OF STUDIES}

\section{Characteristics of included studies [ordered by study ID]}

Brown 1997

\begin{tabular}{|c|c|c|c|}
\hline Methods & \multicolumn{3}{|c|}{$\begin{array}{l}\text { Pill count } \\
\text { Follow up at } 8 \text { months }\end{array}$} \\
\hline Participants & \multicolumn{3}{|c|}{$\begin{array}{l}\mathrm{n}=29 \\
\text { high CHD risk } \\
100 \% \text { male } \\
\text { Mean age } 49 \\
\text { Participants subgroup of FAT study }\end{array}$} \\
\hline Interventions & \multicolumn{3}{|c|}{$\begin{array}{l}\text { Niacin } 1000 \mathrm{mg} \text { twice daily (IVG (intervention group)) } \\
\text { versus } \\
\text { Niacin } 500 \mathrm{mg} \text { four times daily (CG (control group)) } \\
\text { Both groups were on triple therapy consisting of niacin, lovastatin (20mg twice daily) and } \\
\text { colestipol (10gr twice daily) }\end{array}$} \\
\hline \multirow[t]{3}{*}{ Outcomes } & 1 & $\begin{array}{l}\text { ADHEREI } \\
\text { mean adhe }\end{array}$ & $\begin{array}{l}\text { (IVG) versus } 85 \%(\mathrm{CG}) \text { difference in } \\
p=0.01\end{array}$ \\
\hline & 2 & $\begin{array}{l}\text { SERUM L } \\
\text { cholesterol } \\
\text { difference } \\
\text { difference } \\
\text { retrospecti } \\
\text { performed }\end{array}$ & $\begin{array}{l}\text { Significant difference in total } \\
72 \mathrm{mg} / \mathrm{dl}(\mathrm{CG}) \mathrm{p}<0.05 \text { Significant } \\
\text { us } 98 \mathrm{mg} / \mathrm{dl}(\mathrm{CG}) \mathrm{p}<0.005 \text { Significant } \\
\text { J) versus } 1.83 \text { (CG) } \mathrm{p}<0.02 \text { ( provided } \\
\text { y omitted in paper). Recalculation not } \\
\text { lations. }\end{array}$ \\
\hline & 3 & $\begin{array}{l}\text { ADVERSE } \\
\text { flushing (I } \\
\text { in IVG (21 }\end{array}$ & $\begin{array}{l}\text { ported in IVG } 14 / 29 \text { patients without } \\
\text { rted as }<0.005 \text { patient preference higher } \\
.02 \text { ) }\end{array}$ \\
\hline Notes & \multicolumn{3}{|c|}{$\begin{array}{l}\text { crossover design, results have to be considered with caution (see 'limitation of this review') } \\
\text { subgroup of bigger trial high to moderate risk of bias } \\
\text { Some issues about the data (omission of p-value) were clarified and confirmed in helpful } \\
\text { correspondence with the author }\end{array}$} \\
\hline \multicolumn{4}{|l|}{ Risk of bias } \\
\hline Item & \multicolumn{2}{|c|}{ Authors' judgement } & Description \\
\hline Allocation concealment? & \multicolumn{2}{|l|}{ Unclear } & B - Unclear \\
\hline
\end{tabular}

Faulkner 2000

\begin{tabular}{lll}
\hline Methods & $\mathbf{1}$ & ADHERENCE \\
& $\mathbf{1 . 1}$ & Short term pill count at week 12 \\
$\mathbf{1 . 2}$ & long term prescription refill rate at two years \\
$\mathbf{2}$ & SERUM LIPIDS \\
$\mathbf{2 . 1}$ & Short term Total Cholesterol (TC), LDL, HDL and Triglycerides at 12 weeks \\
$\mathbf{2 . 2}$ & Long term Total Cholesterol, LDL,HDL and Triglycerides at 2 years \\
& \\
\hline Participants & n=30 (15 in each group) \\
& patients seen in secondary care post cardiac surgery \\
& Mean age 64 years in IVG / 61 years in CG \\
USA & \\
\hline
\end{tabular}


Interventions
Weekly phone calls by same pharmacist for 12 weeks for information,education and drug couselling.

Emphasis on prevention.

Both IVG and CG were started on statins and resins post allocation, as well as given drug instructions and dietary advice.

Medication used : Lovastatin $20 \mathrm{mg}$ once daily and colestipol (anion-exchange resin) $5 \mathrm{mg}$ twice daily

Outcomes

\section{ADHERENCE}

1.1 short term outcomes reported were non significantly improved for both Statin and Colestipol mean adherence was $88 \%$ in IVG versus $86 \%$ in CG (Statin) mean adherence was $90 \%$ in IVG versus $88 \%$ in CG (Colestipol) p-value reported as $>0.05$ for both

1.2 Long term outcomes reported were significantly improved for both Statin and Colestipol mean adherence was $63 \%$ in IVG versus $39 \%$ in CG (Statin) mean adherence was $48 \%$ in IVG versus $23 \%$ in CG (Colestipol) P-value reported as $<0.05$ for for both Recalculating results was not possible as standard deviations were not reported.

\section{$2 \quad$ SERUM LIPIDS}

2.1 Short term outcomes were reported as non significant differences for cholesterol, LDL,HDL and triglycerides in IVG and CG. The percent change from baseline was compared between IVG and CG. 5.4\% greater reduction for TC $5.2 \%$ greater reduction for LDL $0.1 \%$ greater reduction for HDL $2.6 \%$ greater reduction for TRG p-value was reported as $>0.05$ hence non significant for all Recalculated p-values (ttesti/Stata) confirmed these results.

2.2 Long term outcomes were reported as significant changes for TC,LDL and TRG. These results could not be confirmed by recalculation. Proportional reduction from baseline compared between IVG and CG: $9.1 \%$ greater reduction in IVG for TC ( $p$ reported $<0.03$, if recalculated $p=0.38$ ) $9.9 \%$ greater reduction in IVG for LDL ( $p$ reported $<0.02$, if recalculated $p=0.25$ ) $0.8 \%$ greater reduction in IVG for HDL $(\mathrm{p}$ reported $<0.45$, if recalculated $\mathrm{p}=$ 0.78 ) $6.3 \%$ greater reduction in IVG for TRG (p reported $<0.04$, if recalculated $\mathrm{p}=0.30$ ) Telephone education and reminders improved lipid profile significantly at long term follow up. Very similarly long term but not short term adherence showed a significant improvement in the intervention group compared to the control group. Recalculation did not confirm results for serum lipids. Adherence result could not be confirmed by recalculation as no standard deviations were reported and data was irretrievable Minor error in table III (wrong baseline TC) was detected, which would have had no major impact as only underestimating intervention effect

\begin{tabular}{lll}
\hline Notes & $\begin{array}{l}\text { Moderate risk to bias. Good study design, long follow-up (2 years). } \\
\text { The fact that the p-values for the lipid results could not be reproduced by our own } \\
\text { calculations, casts some doubt upon the outcome for adherence }\end{array}$ \\
\hline Risk of bias & Authors' judgement & Description \\
\hline Item & Yes & A - Adequate \\
\hline Allocation concealment? &
\end{tabular}

Guthrie 2001

\begin{tabular}{ll}
\hline Methods & $\begin{array}{l}\text { Self reported adherence via questionnaire at } 6 \text { months expressed as percentage of patients } \\
\text { taking medication as prescribed }\end{array}$ \\
\hline Participants & $\mathrm{n}=4548$ (3635 in IVG / 913 in CG) \\
& 13100 initially recruited (10335 in IVG / 2765 in CG), response rate only 35\% (35\% in \\
& IVG / 33\% in CG) \\
& Patients with high risk of MI \\
& Primary care setting mostly (90\%) \\
& 49\% male patients in IVG / 47\% in CG \\
Mean age 57 years in IVG/ 58 years in CG \\
USA
\end{tabular}

Interventions

Telephone reminders and early postal reminders in IVG.

Cochrane Database Syst Rev. Author manuscript; available in PMC 2014 September 15. 
Both IVG and CG were started on pravastatin (dose not reported), received lifestyle modification advice by their physician and were sent late postal reminders

\begin{tabular}{|c|c|}
\hline Outcomes & $\begin{array}{l}\text { According to the authors, there were no significant difference in adherence between IVG } \\
\text { and CG. } \\
79.7 \% \text { of patients in the IVG took their medication as prescribed compared to } 77.4 \% \text { of } \\
\text { patients in the CG. } \\
\text { Reporting of side effects in patients who had terminated their medication were similar in } \\
\text { IVG and CG ( } 5.5 \% \text { versus } 5.3 \%) \\
\text { P-values, standard deviations and power calculations were NOT reported }\end{array}$ \\
\hline Notes & $\begin{array}{l}\text { The outcome might have been contaminated by sending late postal reminders to patients } \\
\text { belonging to the control group. } \\
\text { Self report data remained unclear and could not be retrieved from the author of the study. } \\
\text { Overall high risk to bias. }\end{array}$ \\
\hline \multicolumn{2}{|l|}{ Risk of bias } \\
\hline Item & Authors' judgement \\
\hline Allocation concealment? & A - Adequate \\
\hline
\end{tabular}

\section{Marquez 1998}

\begin{tabular}{|c|c|c|}
\hline Methods & \multicolumn{2}{|c|}{$\begin{array}{l}\text { Pill counts over } 4 \text { months. } \\
\text { Surprise pill counts to patients' homes were performed to reduce potential patient } \\
\text { manipulation }\end{array}$} \\
\hline Participants & \multicolumn{2}{|c|}{$\begin{array}{l}\mathrm{n}=110 \text { ( } 55 \text { in each group) } \\
\text { Patients started on lipid lowering medication for mostly primary prevention } \\
\text { Primary care setting in Spain. } \\
35 \% \text { male in IVG / } 41 \% \text { male in CG } \\
\text { Mean age } 55.7 \text { years in IVG / } 56.1 \text { in CG }\end{array}$} \\
\hline Interventions & \multicolumn{2}{|c|}{$\begin{array}{l}\text { Small group training followed by postal back-up consisting of information packages (IVG } \\
\text { only). } \\
\text { Both IVG and CG were started on fluvastatin } 20 \mathrm{mg} \text { once daily post allocation and received } \\
\text { verbal and written information followed by usual care by their General Practitioner }\end{array}$} \\
\hline \multirow[t]{4}{*}{ Outcomes } & 1 & $\begin{array}{l}\text { ADHERENCE No significant difference between IVG and CG (mean } \\
\text { percentage of pills taken). } 88.5 \% \text { of prescribed pills were taken by patients in } \\
\text { IVG versus } 83.8 \% \text { in CG. Difference }=4.7 \% \text {. p reported as }>0.05 \text { This result } \\
\text { was confirmed by recalculated } p=0.084 \text { (ttesti, STATA) }\end{array}$ \\
\hline & 2 & $\begin{array}{l}\text { SERUM LIPIDS Differences between IVG and CG only significant for TRG. } \\
\text { Compared were the final mean endpoint values between groups. } 7.5 \mathrm{mg} / \mathrm{dl} \\
\text { more reduction in mean TC in IVG, } \mathrm{p}>0.05 \mathrm{p}=0.26 * 5.2 \mathrm{mg} / \mathrm{dl} \text { more } \\
\text { reduction in mean LDL in IVG, }>0.05 \mathrm{p}=0.48 *\end{array}$ \\
\hline & 2.1 & $\begin{array}{l}\mathrm{mg} / \mathrm{dl} \text { increase in mean HDL in IVG } \mathrm{p}>0.05 \mathrm{p}=0.48 * 30 \mathrm{mg} / \mathrm{dl} \text { more } \\
\text { reduction in mean TRG in IVG } \mathrm{p}<0.05 \mathrm{p}=0.0019 * \mathrm{p} \text {-value if recalculated } \\
\text { (ttesti, Stata) }\end{array}$ \\
\hline & 3. & $\begin{array}{l}\text { ADVERSE EFFECTS Reported adverse effects lower in IVG ( } 5.5 \% \text { versus } \\
9.2 \%, \text { p reported as non significant) }\end{array}$ \\
\hline Notes & \multicolumn{2}{|c|}{$\begin{array}{l}\text { Complex intervention. } \\
\text { Surprise pill count might increase reliability of adherence results. } \\
\text { Short follow up. } \\
\text { Only final endpoints compared, they were not adjusted for baseline. } \\
\text { Low risk to bias. }\end{array}$} \\
\hline \multicolumn{3}{|l|}{ Risk of bias } \\
\hline Item & \multicolumn{2}{|c|}{ Authors' judgement } \\
\hline Allocation concealment? & \multicolumn{2}{|l|}{ Yes } \\
\hline
\end{tabular}

Poston 1998

Cochrane Database Syst Rev. Author manuscript; available in PMC 2014 September 15. 


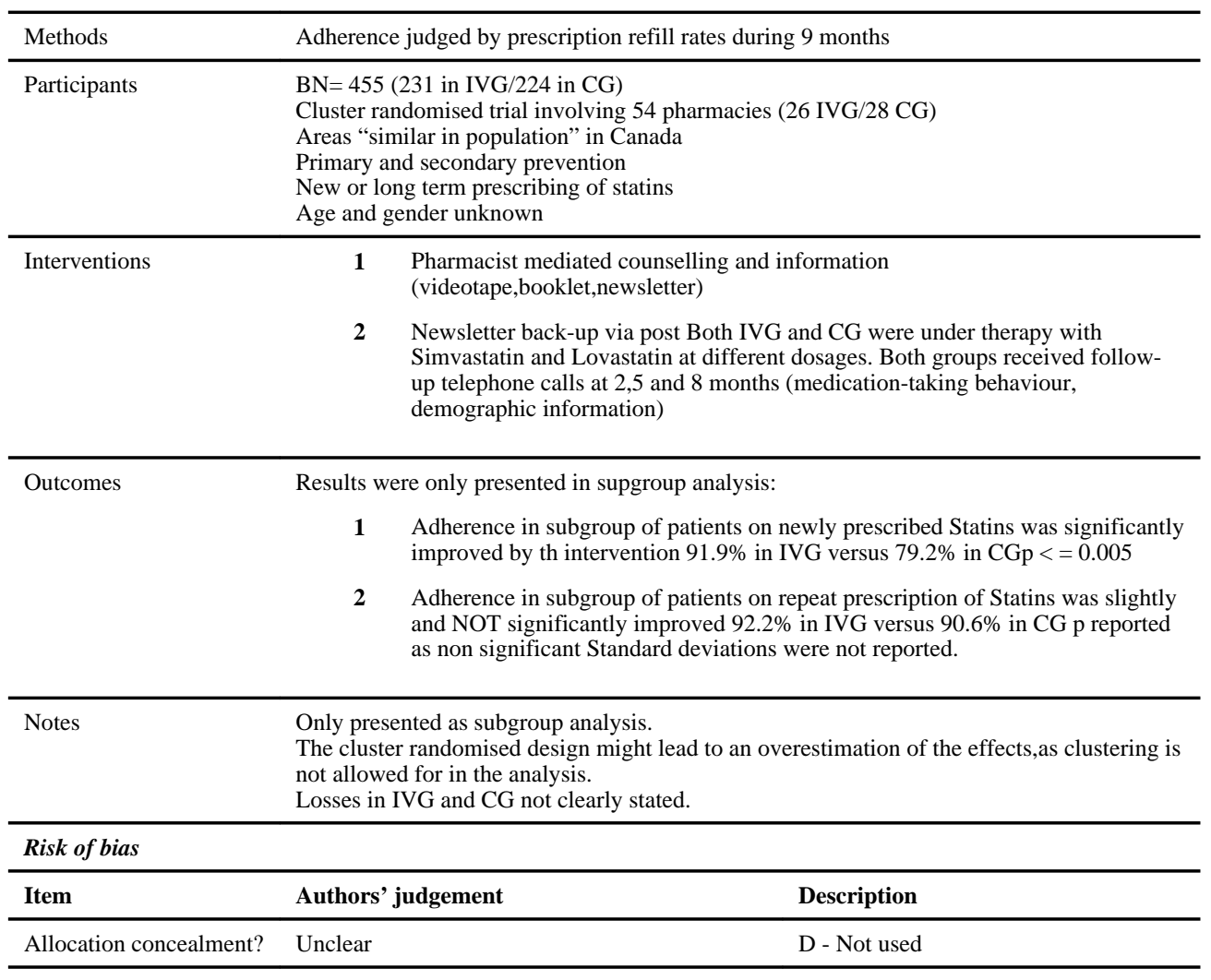

Powell 1995

\begin{tabular}{ll}
\hline Methods & Adherence assessed via prescription refill records for a period of 3 to 9 months \\
\hline Participants & N=568 (271 in IVG/ 297 in CG) \\
& Members of a Health Maintenance Organisation (HMO) on current medication with \\
& Simvastatin. \\
& Primary and secondary prevention \\
& Age and gender not reported \\
& USA
\end{tabular}

Cochrane Database Syst Rev. Author manuscript; available in PMC 2014 September 15. 


\begin{tabular}{lll} 
Allocation concealment? $\quad$ Unclear & B - Unclear \\
\hline
\end{tabular}

\section{Schectman 1994}

\begin{tabular}{|c|c|c|c|}
\hline \multirow[t]{4}{*}{ Methods } & \multicolumn{3}{|c|}{ Medication adherence assessed } \\
\hline & 1 & \multicolumn{2}{|c|}{ Via prescription refill rates for 2 months } \\
\hline & 2 & \multicolumn{2}{|c|}{ Via self-reported discontinuation rates } \\
\hline & 3 & \multicolumn{2}{|c|}{ Via interview } \\
\hline Participants & \multicolumn{3}{|c|}{$\begin{array}{l}\mathrm{n}=40 \text { ( } 18 \text { in IVG / } 22 \text { in CG) in patients taking bile acid sequestrants (cholestyramine } 8 \mathrm{~g} \\
\text { twice daily) } \\
\mathrm{n}=80 \text { ( } 40 \text { in IVG / } 40 \text { in CG) in patients taking Nicotinic acid (niacin } 0.5 \mathrm{~g} \text { three times } \\
\text { daily) } \\
\text { Newly prescribed lipid lowering medication for primary and secondary prevention } \\
\text { Mean age } 59 \text { years in IVG/ } 62 \text { years in CG } \\
\text { mostly male participants }\end{array}$} \\
\hline Interventions & \multicolumn{3}{|c|}{$\begin{array}{l}\text { Telephone contacts to encourage drug continuation ( } 5 \text { contacts in the first month). } \\
\text { Both IVG and CG received oral and written information prior to drug prescription }\end{array}$} \\
\hline \multirow[t]{3}{*}{ Outcomes } & 1 & $\begin{array}{l}\text { Moderate, } \\
\text { both medi } \\
\text { (SE 4) in I } \\
\text { IVG versu }\end{array}$ & $\begin{array}{l}\text { nprovement by early telephone calls in } \\
\text { G p=0 (script refills). BAS group: } 88 \% \\
\text { p }=0.32 \text { NIACIN group: } 90 \% \text { (SE 2) in }\end{array}$ \\
\hline & 2 & $\begin{array}{l}\text { Moderate, } \\
\text { discontinu } \\
\text { BAS grou } \\
34 \% \mathrm{p}=0 .\end{array}$ & $\begin{array}{l}\text { AS) or decrease(NIACIN) in } \\
\text { on groups after } 6 \text { months (self report). } \\
\text { n CG p=0.17 NIACIN group: } 29 \% \text { versus } \\
\text { inuation rates were NOT reported. }\end{array}$ \\
\hline & 3 & $\begin{array}{l}\text { Adherence } \\
\text { pattern of }\end{array}$ & $\begin{array}{l}\text { generally lower, but showed a similar } \\
\text { rovement } \mathrm{i} \text { the intervention groups }\end{array}$ \\
\hline Notes & \multicolumn{3}{|c|}{$\begin{array}{l}\text { Adherence rates in this study do not reflect a mean percentage value like in other studies. } \\
\text { Only patients remaining on treatment are included, excluding patients who discontinued } \\
\text { their medication. } \\
\text { Numbers in BAS group are too low to detect a difference in adherence of } 15 \% \text { according to } \\
\text { power calculations performed by the authors. } \\
\text { Numbers, non-responders and drop-outs remain unclear. }\end{array}$} \\
\hline \multicolumn{4}{|l|}{ Risk of bias } \\
\hline Item & \multicolumn{2}{|c|}{ Authors' judgement } & Description \\
\hline Allocation concealment? & \multicolumn{2}{|l|}{ Yes } & A - Adequate \\
\hline
\end{tabular}

Sweeney 1991

\begin{tabular}{ll}
\hline Methods & Adherence assessed via pill count over 2 months \\
\hline Participants & $\mathrm{n}=83$ (45 in IVG / 38 in CG) \\
& ambulatory care \\
& Primary prevention \\
& $49 \%$ male in IVG / 44\% male in CG \\
& mean age: 55.3 years in IVG/ 55.5 in CG \\
\hline Interventions & $\begin{array}{l}\text { Anion-exchange resins in two different forms: } \\
\text { colestyramine (8g twice daily) in bar form (IVG) } \\
\text { versus colestyramine (8g twice daily) in powder form (CG). }\end{array}$ \\
\hline Outcomes & Mean adherence rate for bar form slightly worse compared with powder form. \\
& Difference non significant.
\end{tabular}

Cochrane Database Syst Rev. Author manuscript; available in PMC 2014 September 15. 


\begin{tabular}{lll} 
& $\begin{array}{l}91.8 \% \text { (SE3.6) in IVG versus 94.8 (SE 2.1) in CG } \\
\text { p>0.05 } \\
\text { if recalculated } \mathrm{p}=0.47\end{array}$ \\
\hline Notes & $\begin{array}{l}\text { Bar form versus powder is very specific for colestyramine and not relevant for other lipid } \\
\text { lowering medication. } \\
\text { Follow up is short. }\end{array}$ \\
\hline Risk of bias & & \\
\hline Item & Authors' judgement & Description \\
\hline Allocation concealment? & Unclear & B - Unclear \\
\hline
\end{tabular}

\section{Characteristics of excluded studies [ordered by study ID]}

\begin{tabular}{|c|c|}
\hline Study & Reason for exclusion \\
\hline Allen 2000 & Adherence outcome only in a subgroup of patients \\
\hline Allen 2002 & Review \\
\hline Alvarez 2001 & Review \\
\hline Anon 2001(a) & No random allocation. \\
\hline Anon 2001(b) & Congress report \\
\hline Anon 2002 & No adherence outcome reported \\
\hline Ashcroft 2001 & Report \\
\hline Athyros $2002 b$ & Intervention not aimed at improving medication adherence \\
\hline Baillargeon 2001 & No RCT design \\
\hline Becker 1998 & Intervention aimed at improved prescribing \\
\hline Becker 2001 & Review \\
\hline Bogden 1997 & intervention not aimed at improving medication adherence \\
\hline Bozovich 2000 & Non-random allocation \\
\hline Bruckert 1999 & $\begin{array}{l}\text { Subtrial looking at information leaflets as adherence-enhancing intervention. Data are not } \\
\text { available and were never published due to non significant effect }\end{array}$ \\
\hline Burkett 1990 & Intervention not aimed at improving medication adherence \\
\hline Casebeer 1999 & Intervention aimed at influence physicians' behaviour \\
\hline Coates 1982 & Intervention not aimed at improving adherence to hypolipidaemics \\
\hline Copher 2002 & Before/after comparison \\
\hline DeBusk 1994 & No adherence outcome reported. \\
\hline Diabetes 2000 & Intervention not aimed at improving medication adherence \\
\hline Ditusa 2001 & No RCT \\
\hline Diwan 1995 & Intervention aimed at influence physicians' behaviour \\
\hline Dobs 1994 & Intervention not aimed at improving medication adherence \\
\hline Dunham 2000 & No adherence outcome \\
\hline Ebrahim 2000 & Review \\
\hline Ellis 1998 & Comment \\
\hline Ellis 2000 & Intervention not aimed at patient adherence \\
\hline Eriksson M, Had2 & Adherence comparison of classes of hypolipidemics \\
\hline
\end{tabular}




\begin{tabular}{|c|c|}
\hline Frances 2001 & Intervention not aimed at patient adherence \\
\hline Friedman 1998 & Intervention not aimed at medication adherence \\
\hline Gaede 1999 & Intervention not aimed at improving medication adherence \\
\hline Gaede 2003 & Intervention not aimed at improving medication adherence \\
\hline Insull 1997 & Review \\
\hline Ives 1993 & Intervention not aimed at improving medication adherence \\
\hline Jackevicius 2002 & Cohort study \\
\hline Johannesson 1996 & No adherence outcome reported \\
\hline Jolly 1998 & Not concerned with lipidaemia \\
\hline Keyserling 1997 & Intervention not aimed at improving medication adherence \\
\hline Kim 2002 & Observational study \\
\hline Kinn 2001 & No RCT \\
\hline Kiortsis 2000 & Cross sectional study \\
\hline Kirkman 1994 & Intervention not aimed at improving medication adherence \\
\hline Kjelsberg 1990 & Intervention not aimed at improving medication adherence \\
\hline Konzem 1997 & No random allocation \\
\hline Kuznar 2002 & Comment \\
\hline LaRosa 2000 & Review \\
\hline LaRosa JH, LaRo2 & Review \\
\hline Lesaffre 20001 & Not concerned with lipidaemia \\
\hline Lindholm 1996 & Intervention not aimed at improving medication adherence \\
\hline Merriam 1997 & Intervention not aimed at improving medication adherence \\
\hline Micevski 2002 & Review \\
\hline Moher 2001 & Intervention aimed at influence prescribing \\
\hline Noel 2002 & Letter \\
\hline O’Donnell 2001-1 & No RCT design \\
\hline O’Donnell 2001-2 & No RCT design \\
\hline Oi 1998 & No adherence outcome reported \\
\hline Pineiro 1997 & No RCT design \\
\hline Rachmani 2002 & No adherence outcome reported \\
\hline Rastam 1996 & Intervention not aimed at improving medication adherence \\
\hline Rindone 1998 & No adherence outcome reported \\
\hline Robin 2002 & Review \\
\hline Rodgers 2000 & Review \\
\hline Schectman 1996 & Only maintainance rates in subgroup reported \\
\hline Scherwitz 1995 & Intervention not aimed at improving medication adherence \\
\hline Schwed 1999 & No RCT design \\
\hline Senaratne 2001 & No RCT design \\
\hline Shaffer 1995 & Intervention not aimed at improving medication adherence \\
\hline Shively 1991 & Review \\
\hline
\end{tabular}

Cochrane Database Syst Rev. Author manuscript; available in PMC 2014 September 15. 


\begin{tabular}{ll} 
Simpson 2001 & Intervention not aimed at improving medication adherence \\
\hline Tsuyuki 1999 & Intervention not aimed at improving medication adherence \\
\hline Tsuyuki 2002 & Review \\
\hline Tully 2000 & Review \\
\hline Urquhart 1999 & Review \\
\hline Vale 2002 & Adherence outcome not reported \\
\hline Velonakis 1999 & No random allocation \\
\hline Verges 1998 & No random allocation \\
\hline Wahlstrom 1995 & Intervention aimed at influence prescribing \\
\hline Wei 2002 & No RCT design \\
\hline Wright 2002 & Reveiw \\
\hline Zermansky 2002 & Not concerned with lipidaemia \\
\hline
\end{tabular}

\section{Characteristics of ongoing studies [ordered by study ID]}

De Klerk 2003

\begin{tabular}{ll}
\hline Trial name or title & Improved compliance and persistence with atorvastatin through a pharmacy -based intervention \\
\hline Methods & \\
\hline Participants & $\begin{array}{l}393 \text { patients with elevated cholesterol levels and on Atorvastatin } \\
\text { IVG }=194 \\
\end{array}$ \\
\hline CG n $=199$ \\
\hline Interventions & pharmacist review, electronic and educational reminding \\
\hline Outcomes & Intervention improved patient adherence and persistence with atorvastatin. \\
& prescribed dosis taken 98.9\% (IVG) versus 95.2\% (CG), p< 0.001 \\
\hline Starting date & not reported \\
\hline Contact information & Eric de Klerk \\
\hline Notes & abstract submitted to ISPOR \\
\hline
\end{tabular}

\section{DATA AND ANALYSES}

This review has no analyses.

\section{ADDITIONAL TABLES}

Table 1

Search Strategy for CENTRAL

\begin{tabular}{cl}
\hline Issue 1, 2003 \\
\hline$\# \mathbf{1}$ & compliance \\
$\# \mathbf{2}$ & non-compliance \\
$\# \mathbf{3}$ & noncompliance \\
$\# \mathbf{4}$ & adher*
\end{tabular}




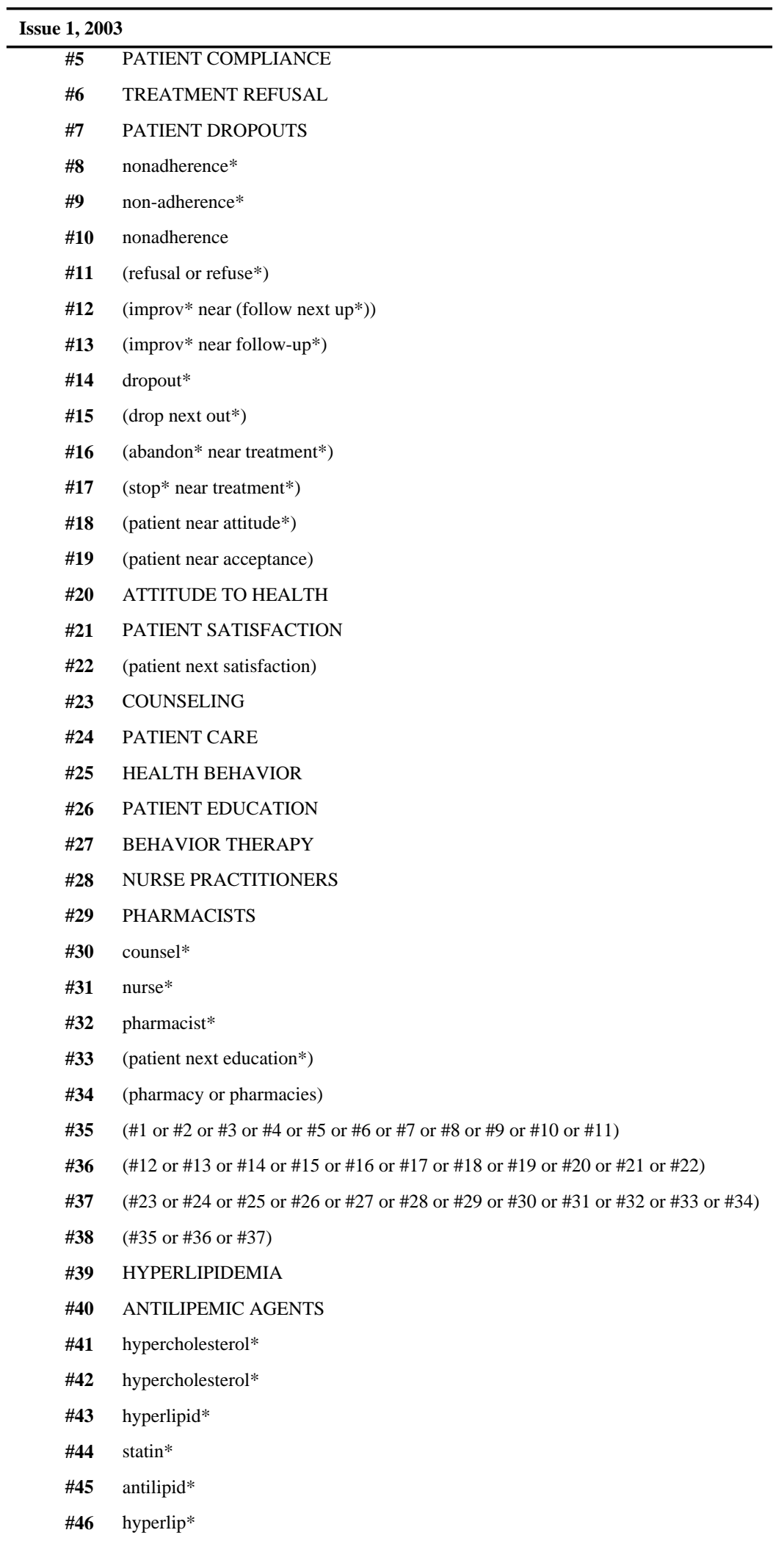




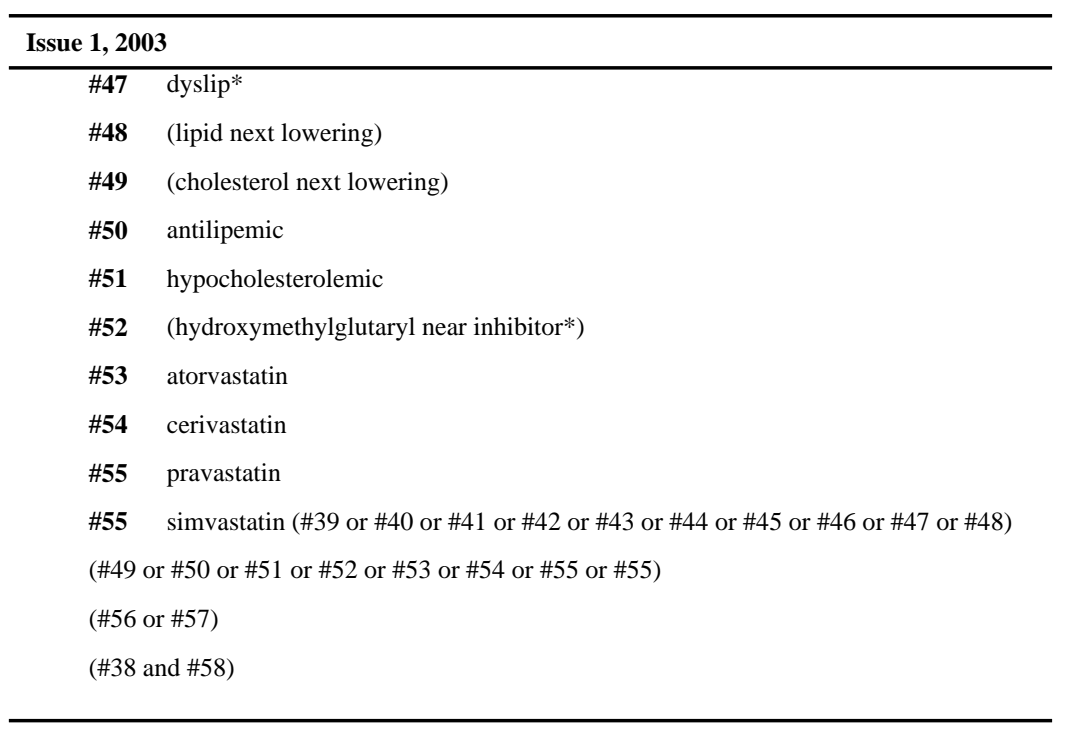

Table 2

Seach Strategy for EMBASE

Jan1998 to Feb 2003

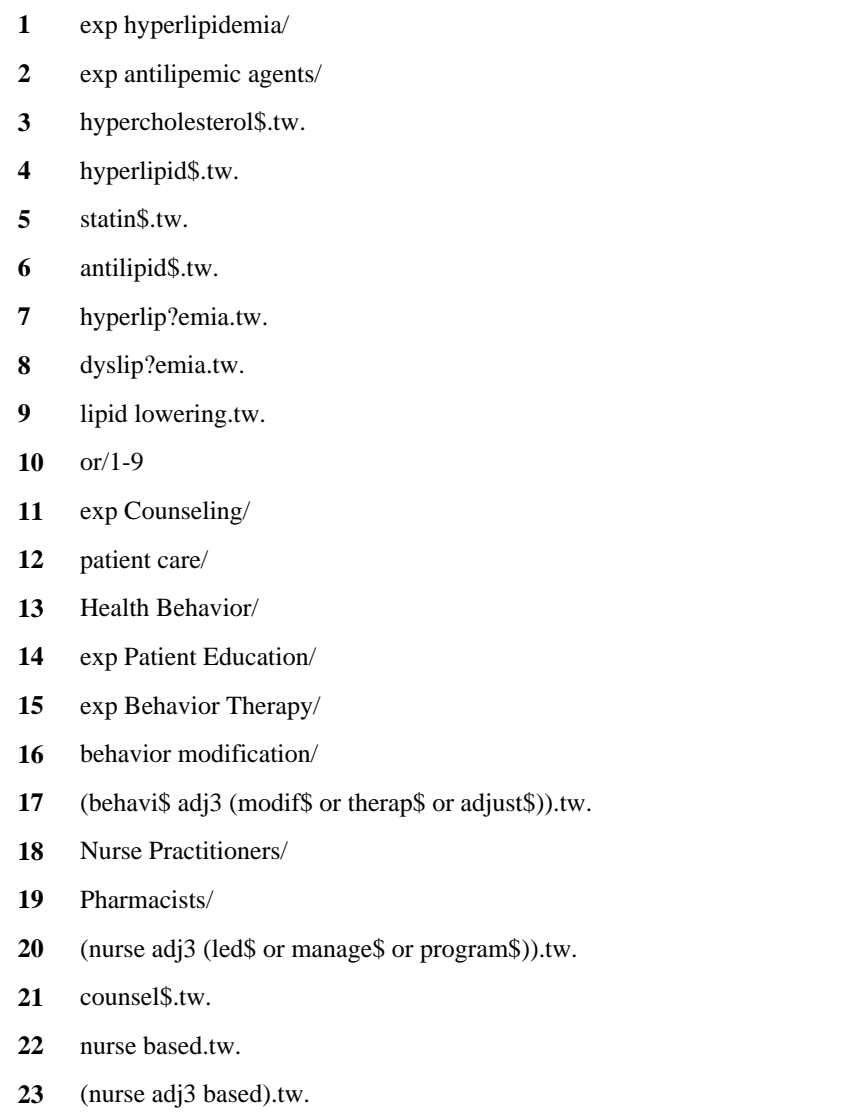




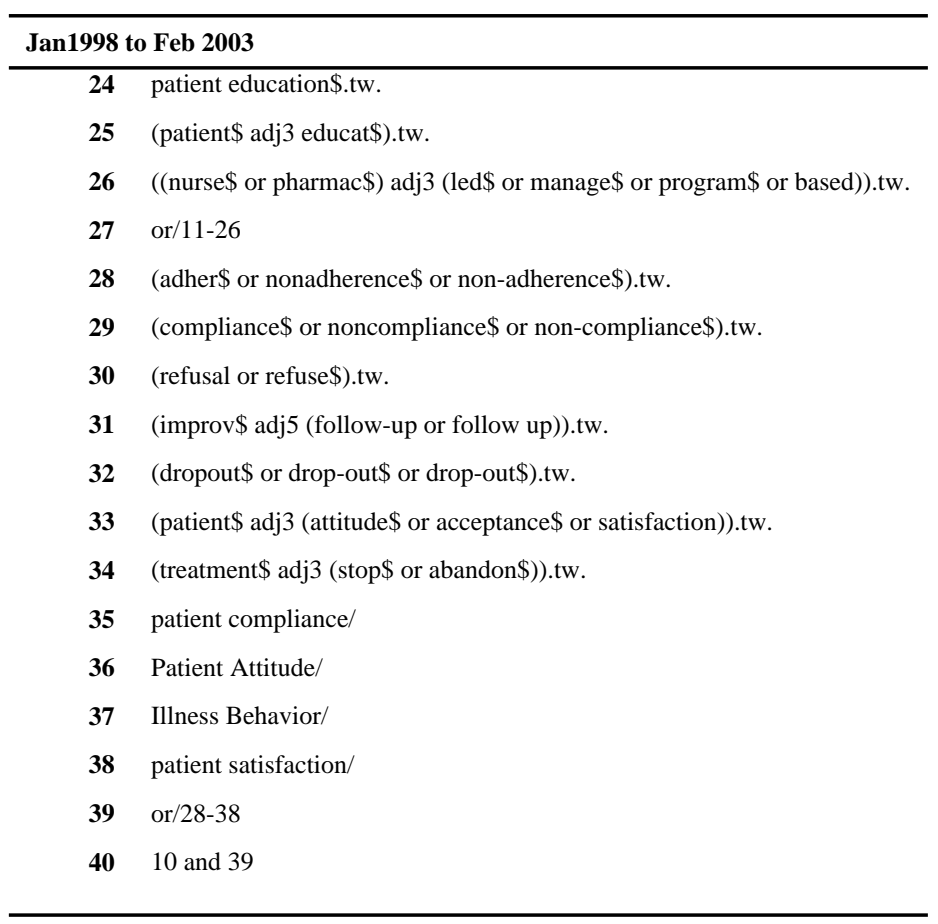

Table 3

Search Strategy for CINAHL

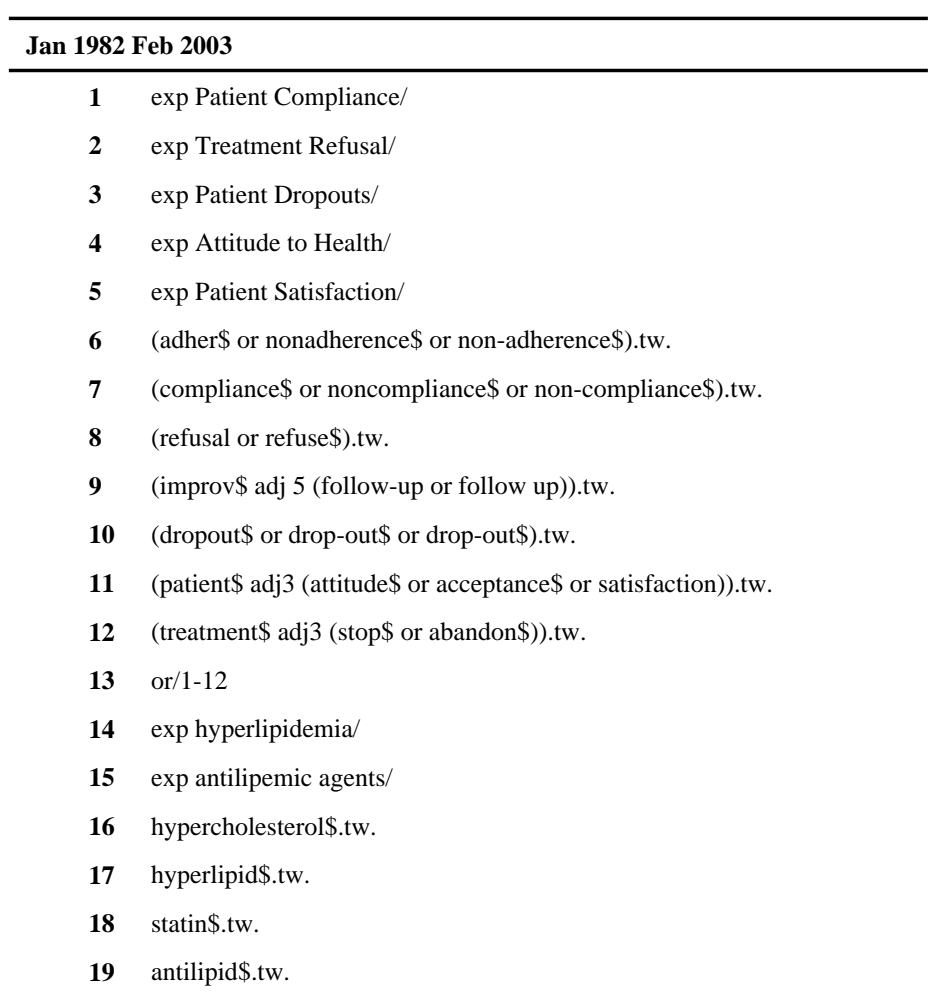




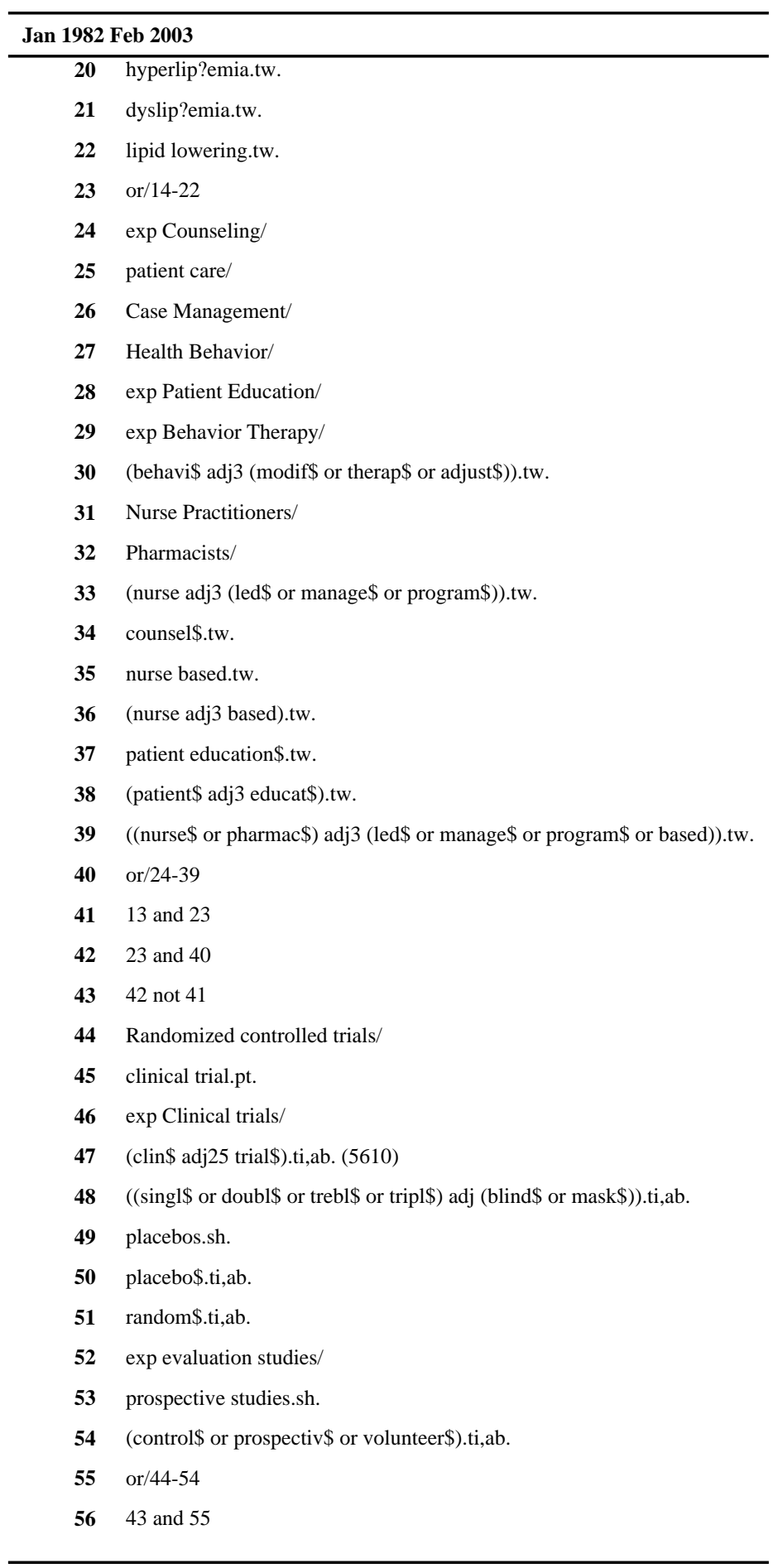


Table 4

\section{Search Strategy for PsychINFO}

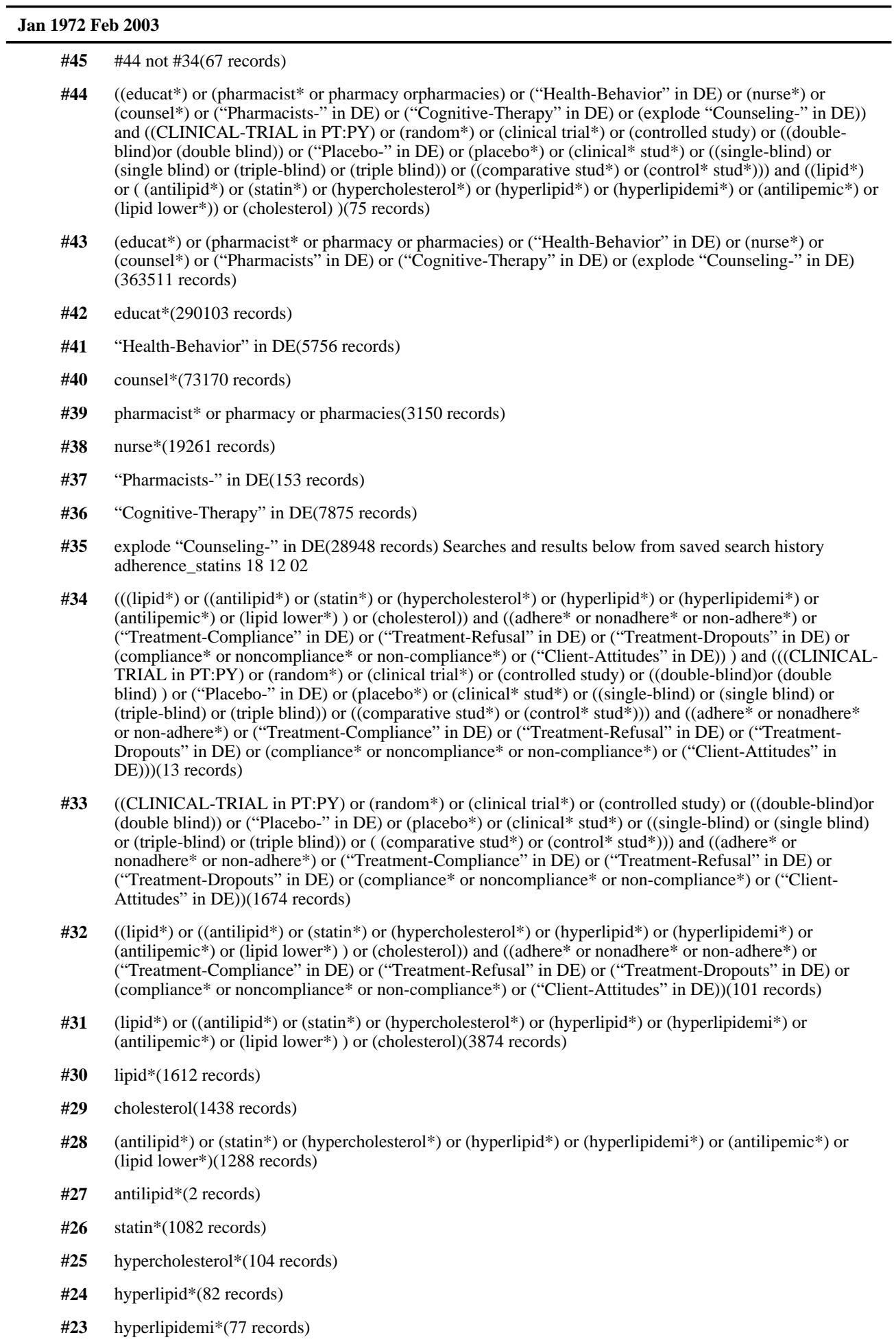




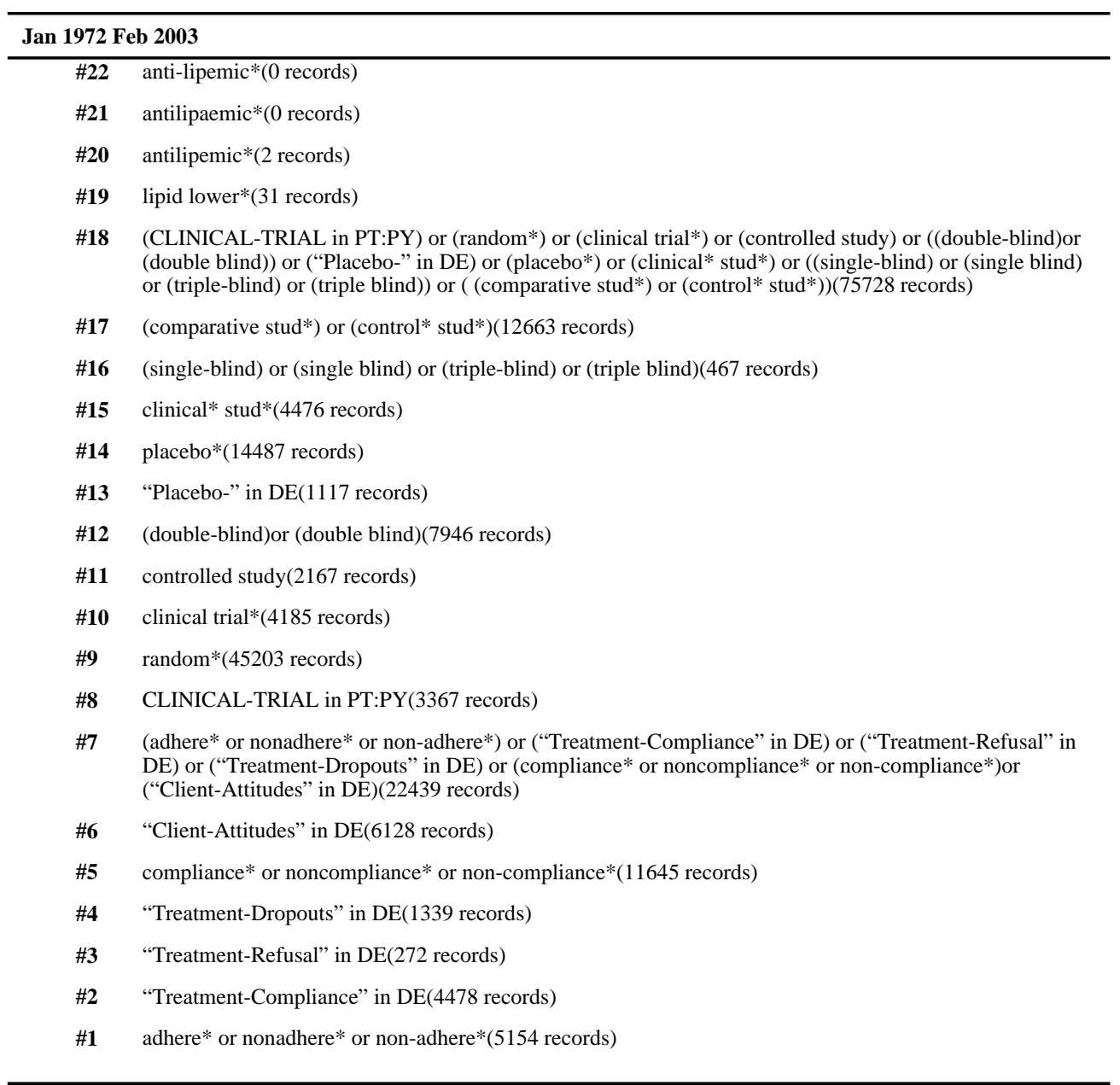

\section{WHAT'S NEW}

Last assessed as up-to-date: 31 July 2004.

\begin{tabular}{lll}
\hline Date & Event & Description \\
\hline 9 September 2008 & Amended & Converted to new review format. \\
\hline
\end{tabular}

\section{HISTORY}

Protocol first published: Issue 3, 2003

Review first published: Issue 4, 2004 


\begin{tabular}{lll}
\hline Date & Event & Description \\
\hline 1 August 2004 & New citation required and conclusions have changed & Substantive amendment \\
\hline
\end{tabular}

\section{References to studies included in this review}

*Indicates the major publication for the study

Brown 1997 \{published data only . Brown BG, Bardsley J, Poulin D, Hillger LA, Dowdy A, Maher VM, et al. Moderate dose, three-drug therapy with niacin, lovastatin, and colestipol to reduce low-density lipoprotein cholesterol $<100 \mathrm{mg} / \mathrm{dl}$ in patients with hyperlipidemia and coronary artery disease. American Journal of Cardiology. 1997; 80(2):111-5. [PubMed: 9230143]

Faulkner 2000 \{published data only\} . Faulkner MA, Wadibia EC, Lucas BD, Hilleman DE. Impact of pharmacy counseling on compliance and effectiveness of combination lipid-lowering therapy in patients undergoing coronary artery revascularization: a randomized, controlled trial. Pharmacotherapy. 2000; 20(4)

Guthrie 2001 \{published data only\} . Guthrie RM. The effects of postal and telephone reminders on compliance with pravastatin therapy in a national registry: results of the first myocardial infarction risk reduction program. Clinical Therapeutics. 2001; 23(6):970-80. [PubMed: 11440296]

Marquez 1998 \{published data only\} . Marquez CE, Casado-Martinez JJ, Lopez dA, Cores PE, Lopez-Zamorano JM, Moreno-Garcia JP, et al. Therapeutic compliance in dyslipidemias. A trial of the efficacy of health education. Atencion Primaria. 1998; 22(2):79-84. [PubMed: 9717348]

Poston 1998 \{published data only\} . Poston J, Loh E, Dunham W. The medication use study. Canadian Pharmaceutical Journal. 1998; 131(10):31-8.

Powell 1995 \{published data only\}. Powell KM, Edgren B. Failure of educational videotapes to improve medication compliance in a health maintenance organization. American Journal of Health-System Pharmacy. 1995; 52(20):2196-9. MEDLINE: Medline 96119408. [PubMed: 8564589]

Schectman 1994 \{published data only\} . Schectman G, Hiatt J, Hartz A. Telephone contacts do not improve adherence to niacin or bile acid sequestrant therapy. Annals of Pharmacotherapy. 1994; 28(1):29-35. MEDLINE: Medline 94169490 embase 1994045930. [PubMed: 8123955]

Sweeney 1991 \{published data only\} . Sweeney ME, Fletcher BJ, Rice CR, Berra KA, Rudd CM, Fletcher GF, et al. Efficacy and compliance with cholestyramine bar versus powder in the treatment of hyperlipidemia. American Journal of Medicine. 1991; 90(4):469-73. MEDLINE: Medline 91189189. [PubMed: 2012087]

\section{References to studies excluded from this review}

Allen 2000 \{published data only . Allen JK. Cholesterol management: an opportunity for nurse case managers. Journal of Cardiovascular Nursing. 2000; 14(2):50-8. [PubMed: 10653276]

Allen 2002 \{published data only\} . Allen JK, Blumenthal RS, Margolis S, Rohm YD, Miller ER III, Kelly K. Nurse case management of hypercholesterolemia in patients with coronary heart disease: Results of a randomized clinical trial. American Heart Journal. 2002; 144(4):678-86. [PubMed: 12360165]

Alvarez 2001 \{published data only\} . Alvarez MS, Gomez de la Fuente FJ, Gallego CP, Picon Garcia dL. Effectuve strategies to improve adherence to drug prescription. Medifam - Revista de Medicina Familiar y Comunitaria. 2001; 11(8):467-71.

Anon 2001(a) \{published data only\}. Anonymous. Pharmacist-managed lipid program reduces medication costs despite increase in drug utilization. Hospital Formulary. 2001; 36(5):378-80. 
Anon 2001(b) \{published data only . Anonymous. Risk factors for CHD not being identified. British Journal of Cardiology. 2001; 8(6):356-8.

Anon 2002 \{published data only\} . Anonymous. Is alternate day dosing more cost-effective? Pharmaceutical Journal. 2002; 269(7224):706.

Ashcroft 2001 \{published data only\} . Ashcroft DM, Chapman S, Lockett J. Supporting the implementation of prescribing advice in PCOs. Pharmaceutical Journal. 2001; 267(7170):558-9.

Athyros 2002b \{published data only . Athyros VG, Mikhailidis DP, Papageorgiou AA, Mercouris BR, Athyrou VV, Symeonidis AN, et al. Attaining United Kingdom-European Atherosclerosis Society low-density lipoprotein cholesterol guideline target values in the GREek Atorvastatin and Coronary-heart-disease Evaluation (GREACE) study. Current Medical Research \& Opinion. 2002; 18(8):499-502. [PubMed: 12564661]

Baillargeon 2001 \{published data only\} . Baillargeon JP, Lepage S, Larrivee L, Roy M-A, Landry $\mathrm{S}$, Maheux P. Intensive surveillance and treatment of dyslipidemia in the postinfarct patient: Evaluation of a nurse-oriented management approach. Canadian Journal of Cardiology. 2001; 17(2):169-75. [PubMed: 11223487]

Becker 1998 \{published data only\} . Becker DM, Raqueno JV, Yook RM, Kral BG, Blumenthal RS, Moy TF, et al. Nurse-mediated cholesterol management compared with enhanced primary care in siblings of individuals with premature coronary disease. Archives of Internal Medicine. 1998; 158(14):1533-9. [PubMed: 9679794]

Becker 2001 \{published data only\} . Becker DM, Allen JK. Improving compliance in your dyslipidemic patient: an evidence-based approach. Journal of the American Academy of Nurse Practitioners. 2001; 13(5):200-7. [PubMed: 11930470]

Bogden 1997 \{published data only\} . Bogden PE, Koontz LM, Williamson P, Abbott RD. The physician and pharmacist team. An effective approach to cholesterol reduction. Journal of General Internal Medicine. 1997; 12(3):158-64. MEDLINE: Medline 97254730. [PubMed: 9100140]

Bozovich 2000 \{published data only\} . Bozovich M, Rubino CM, Edmunds J. Effect of a clinical pharmacist-managed lipid clinic on achieving National Cholesterol Education Program lowdensity lipoprotein goals. Pharmacotherapy. 2000; 20(11):1375-83. [PubMed: 11079286]

Bruckert 1999 \{published data only\} . Bruckert E, Simonetta C, Giral P. Compliance with fluvastatin treatment characterization of the noncompliant population within a population of 3845 patients with hyperlipidemia: CREOLE Study Team. Journal of Clinical Epidemiology. 1999; 52(6):589-94. [PubMed: 10408999]

Burkett 1990 \{published data only\} . Burkett PA, Southard DR, Herbert WG, Walberg J. Frequent cholesterol feedback as an aid in lowering cholesterol levels. Journal of Cardiopulmonary Rehabilitation. 1990; 10(4):141-6. MEDLINE: Embase 1990218703.

Casebeer 1999 \{published data only\} . Casebeer LL, Klapow JC, Centor RM, Stafford MA, Renkl LA, Mallinger AP, et al. An intervention to increase physicians' use of adherence-enhancing strategies in managing hypercholesterolemic patients. Academic Medicine. 1999; 74(12):1334-9. [PubMed: 10619013]

Coates 1982 \{published data only . Coates TJ, et al. Frequency of contact and monetary reward in weight loss, lipid change, and blood pressure reduction with adolescents. Behavior-Therapy. 1982; 13(2):175-85. MEDLINE: psycinfo.

Copher 2002 \{published data only\} . Copher HR, Stewart RD. Daily dosing versus alternate-day dosing of simvastatin in patients with hypercholesterolemia. Pharmacotherapy. 2002; 22(9 I): 1110-6. [PubMed: 12222546]

DeBusk 1994 \{published data only\} . DeBusk RF, Miller NH, Superko HR, Dennis CA, Thomas RJ, Lew HT, et al. A case-management system for coronary risk factor modification after acute myocardial infarction. Annals of Internal Medicine. 1994; 120(9):721-9. MEDLINE: Medline 94197361. [PubMed: 8147544]

Diabetes 2000 \{published data only\} . The Diabetes Prevention Program Research Group. The Diabetes Prevention Program: baseline characteristics of the randomized cohort. Diabetes Care. 2000; 23(11):1619-29. MEDLINE: Medline 20540820. [PubMed: 11092283] 
Ditusa 2001 \{published data only\} . Ditusa L, Luzier AB, Brady PG, Reinhardt RM, Snyder BD. A pharmacy-based approach to cholesterol management. American Journal of Managed Care. 2001; 7(10):973-79. MEDLINE: Medline 21525530. [PubMed: 11669361]

Diwan 1995 \{published data only\} . Diwan VK, Wahlstrom R, Tomson G, Beermann B, Sterky G, Eriksson B. Effects of "group detailing" on the prescribing of lipid-lowering drugs: a randomized controlled trial in Swedish primary care. Journal of Clinical Epidemiology. 1995; 48(5):705-11. MEDLINE: Medline 95248412. [PubMed: 7730925]

Dobs 1994 \{published data only\} . Dobs AS, Masters RB, Rajaram L, Stillman FA, Wilder LB, Margolis S, et al. A comparison of education methods and their impact on behavioral change in patients with hyperlipidemia. Patient Education \& Counseling. 1994; 24(2):157-64. MEDLINE: Medline 95265564. [PubMed: 7746765]

Dunham 2000 \{published data only . Dunham DM, Stewart RD, Laucka PV. Low-densitylipoprotein cholesterol in patients treated by a lipid clinic versus a primary care clinic. American Journal of Health-System Pharmacy. 2000; 57(24):2285-6. [PubMed: 11146975]

Ebrahim 2000 \{published data only\} . Ebrahim S, Davey SG. In people with no evidence of cardiovascular disease, how effective are interventions aimed at controlling risk factors in reducing all-cause and coronary artery disease mortality? Western Journal of Medicine. 2000; 173(3):185-6. [PubMed: 10986185]

Ellis 1998 \{published data only\} . Ellis CJ, O’Meeghan T, Hamer AW, Gordon GD, Patel H. Evidence based strategies for secondary prevention of ischaemic heart disease: Time to improve clinical practice. New Zealand Medical Journal. 1998; 1111(1065):170-2. [PubMed: 9612486]

Ellis 2000 \{published data only\} . Ellis SL, Carter BL, Malone DC, Billups SJ, Okano GJ, Valuck $\mathrm{RJ}$, et al. Clinical and economic impact of ambulatory care clinical pharmacists in management of dyslipidemia in older adults: the IMPROVE study. Impact of Managed Pharmaceutical Care on Resource Utilization and Outcomes in Veterans Affairs Medical Centers. Pharmacotherapy. 2000; 20(12):1508-16. MEDLINE: Medline 21012407. [PubMed: 11130223]

Eriksson M, Had2 \{published data only\} . Eriksson M, Hadell K, Holme I, Walldius G, Kjellstrom T. Compliance with and efficacy of treatment with pravastatin and cholestyramine: A randomized study on lipid-lowering in primary care. Journal of Internal Medicine. 1998; 243(5): 373-80. [PubMed: 9651560]

Frances 2001 \{published data only . Frances CD, Alperin P, Adler JS, Grady D. Does a fixed physician reminder system improve the care of patients with coronary artery disease? A randomized controlled trial. Western Journal of Medicine. 2001; 175(3):165-6. [PubMed: 11527840]

Friedman 1998 \{published data only\} . Friedman RH. Automated telephone conversations to assess health behavior and deliver behavioral interventions. Journal of Medical Systems. 1998; 22(2):95-102. [PubMed: 9571516]

Gaede 1999 \{published data only\} . Gaede P, Vedel P, Parving HH, Pedersen O. Intensified multifactorial intervention in patients with type 2 diabetes mellitus and microalbuminuria: the Steno type 2 randomised study. Lancet. 1999; 353(9153):617-22. MEDLINE: Medline 99153397. [PubMed: 10030326]

Gaede 2003 \{published data only . Gaede P, Vedel P, Larsen N, Jensen GV, Parving HH, Pedersen O. Multifactorial intervention and cardiovascular disease in patients with type 2 diabetes. New England Journal of Medicine. 2003; 348(5):383-93. [PubMed: 12556541]

Insull 1997 \{published data only\} . Insull W. The problem of compliance to cholesterol altering therapy. Journal of Internal Medicine. 1997; 241(4):317-25. [PubMed: 9159603]

Ives 1993 \{published data only . Ives DG, Kuller LH, Traven ND. Use and outcomes of a cholesterol-lowering intervention for rural elderly subjects. American Journal of Preventive Medicine. 1993; 9(5):274-81. MEDLINE: Medline 94079785. [PubMed: 8257616]

Jackevicius 2002 \{published data only\} . Jackevicius CA, Mamdani M, Tu JV. Adherence with statin therapy in elderly patients with and without acute coronary syndromes. JAMA. 2002; 288(4):462-7. [PubMed: 12132976]

Johannesson 1996 \{published data only\} . Johannesson M, Borgquist L, Jonsson B, Lindholm LH, The CELL Study Group. The cost effectiveness of lipid lowering in Swedish primary health care. 
Journal of Internal Medicine. 1996; 240(1):23-9. MEDLINE: Medline 96332305. [PubMed: 8708587]

Jolly 1998 \{published data only . Jolly K, Bradley F, Sharp S, Smith H, Mant D. Follow-up care in general practice of patients with myocardial infarction or angina pectoris: initial results of the SHIP trial. Southampton Heart Integrated Care Project. Family Practice. 1998; 15(6):548-55. MEDLINE: Medline 99176682. [PubMed: 10078796]

Keyserling 1997 \{published data only\} . Keyserling TC, Ammerman AS, Davis CE, Mok MC, Garrett J, Simpson R Jr. A randomized controlled trial of a physician-directed treatment program for low-income patients with high blood cholesterol: the Southeast Cholesterol Project. Archives of Family Medicine. 1997; 6(2):135-45. Comment in: Arch Fam Med.1997 Mar-Apr, 6(2):146-7, 9075449. MEDLINE: Medline 97229885. [PubMed: 9075448]

Kim 2002 \{published data only\} . Kim YS, Sunwoo S, Lee HR, Lee KM, Park YW, Shin HC, et al. Determinants of non-compliance with lipid-lowering therapy in hyperlipidemic patients. Pharmacoepidemiology \& Drug Safety. 2002; 11(7):593-600. [PubMed: 12462137]

Kinn 2001 \{published data only\} . Kinn JW, O’Toole MF, Rowley SM, Marek JC, Bufalino VJ, Brown AS. Effectiveness of the electronic medical record in cholesterol management in patients with coronary artery disease (Virtual Lipid Clinic). American Journal of Cardiology. 2001; 88(2): 163-5. [PubMed: 11448414]

Kiortsis 2000 \{published data only\} . Kiortsis DN, Giral P, Bruckert E, Turpin G. Factors associated with low compliance with lipid-lowering drugs in hyperlipidemic patients. Journal of Clinical Pharmacy \& Therapeutics. 2000; 25(6):445-51. [PubMed: 11123498]

Kirkman 1994 \{published data only\} . Kirkman MS, Weinberger M, Landsman PB, Samsa GP, Shortliffe EA, Simel DL, et al. A telephone-delivered intervention for patients with NIDDM. Effect on coronary risk factors. Diabetes Care. 1994; 17(8):840-6. MEDLINE: Medline 95044714 embase 1994240017. [PubMed: 7956628]

Kjelsberg 1990 \{published data only\} . Kjelsberg MO. Mortality after 10one-half years for hypertensive participants in the multiple risk factor intervention trial. Circulation. 1990; 82(5): 1616-28. [PubMed: 2225366]

Konzem 1997 \{published data only\} . Konzem SL, Gray DR, Kashyap ML. Effect of pharmaceutical care on optimum colestipol treatment in elderly hypercholesterolemic veterans. Pharmacotherapy. 1997; 17(3):576-83. [PubMed: 9165562]

Kuznar 2002 \{published data only\} . Kuznar W. Protocol helps drug adherence. Cardiology Review. 2002; 19(3):6.

LaRosa 2000 \{published data only\} . LaRosa JC. Poor compliance: the hidden risk factor. Current Atherosclerosis Reports. 2000; 2(1):1-4. [PubMed: 11122718]

LaRosa JH, LaRo2 \{published data only\} . LaRosa JH, LaRosa JC. Enhancing drug compliance in lipid-lowering treatment. Archives of Family Medicine. 2000; 9(10):1169-75. [PubMed: $11115225]$

Lesaffre 20001 \{published data only\} . Lesaffre E, de Klerk E. Estimating the power of compliance - Improving methods. Controlled Clinical Trials. 2000; 21(6):540-51. [PubMed: 11146148]

Lindholm 1996 \{published data only\} . Lindholm LH, Ekbom T, Dash C, Isacsson A, Schersten B. Changes in cardiovascular risk factors by combined pharmacological and nonpharmacological strategies: the main results of the CELL Study. Journal of Internal Medicine. 1996; 240(1):1322. [PubMed: 8708586]

Merriam 1997 \{published data only\} . Merriam PA, Ockene IS, Hebert JR, Ma Y. A lipid trial tracking system. Journal of Public Health Management \& Practice. 1997; 3(6):74-8. MEDLINE: Medline 98431092. [PubMed: 10183187]

Micevski 2002 \{published data only\} . Micevski V. Review: multidisciplinary disease management programmes do not reduce death or recurrent myocardial infarction but reduce admission to hospital. Evidence-Based Nursing. 2002; 5(2):54. [PubMed: 11995657]

Moher 2001 \{published data only\} . Moher M, Yudkin P, Wright L, Turner R, Fuller A, Schofield $\mathrm{T}$, et al. Cluster randomised controlled trial to compare three methods of promoting secondary 
prevention of coronary heart disease in primary care. BMJ. 2001; 322(7298):1338-42. [PubMed: 11387182]

Noel 2002 \{published data only\} . Noel F, Berringer R, Patel U. Effect of early telephone and postal reminders on medication compliance with pravastatin therapy. Clinical Therapeutics. 2002; 24(1):205-8. [PubMed: 11833833]

O'Donnell 2001-1 \{published data only\} . O'Donnell DC, Chen NTW, Piziak VK. Goal attainment and maintenance of serum cholesterol level in a pharmacist-coordinated lipid clinic. American Journal of Health-System Pharmacy. 2001; 58(4):325-30. [PubMed: 11225170]

O'Donnell 2001-2 \{published data only\} . O'Donnell DC, Brown CM, Piziak VK. Alternative therapy use and adherence to antihyperlipidemic drugs in a lipid clinic. American Journal of Health-System Pharmacy. 2001; 58(11):1017-21. [PubMed: 11402475]

Oi 1998 \{published data only\} . Oi K, Komori H. Escape phenomenon with pravastatin during long-term treatment of patients with hyperlipidemia associated with diabetes mellitus. Current Therapeutic Research, Clinical \& Experimental. 1998; 59(2):130-8.

Pineiro 1997 \{published data only . Pineiro F, Gil V, Donis M, Orozco D, Torres MT, Merino J. The validity of 6 indirect methods for assessing compliance with pharmacological treatment in dyslipidemias. Atencion Primaria. 1997; 19(9):465-8. [PubMed: 9264681]

Rachmani 2002 \{published data only\} . Rachmani R, Levi Z, Slavachevski I, Avin M, Ravid M. Teaching patients to monitor their risk factors retards the progression of vascular complications in high-risk patients with Type 2 diabetes mellitus: a randomized prospective study. Diabetic Medicine. 2002; 19(5):385-92. [PubMed: 12027926]

Rastam 1996 \{published data only\} . Rastam L, Frick J-O. Nurses counseling for hypercholesterolemia: Efficient strategy in middle-aged men. Cardiovascular Risk Factors. 1996; 6(1):36-41.

Rindone 1998 \{published data only\} . Rindone JP, Hiller D, Arriola G. A comparison of fluvastatin $40 \mathrm{mg}$ every other day versus $20 \mathrm{mg}$ every day in patients with hypercholesterolemia. Pharmacotherapy. 1998; 18(4):836-9. MEDLINE: Medline 98355406. [PubMed: 9692657]

Robin 2002 \{published data only\} . Robin DM, Giordani PJ, Lepper HS, Croghan TW. Patient adherence and medical treatment outcomes: a meta-analysis. Medical Care. 2002; 40(9):794811. [PubMed: 12218770]

Rodgers 2000 \{published data only\} . Rodgers J. Pharmacological interventions in type 2 diabetes: the role of nurses. British Journal of Nursing. 2000; 9(13):866-70. [PubMed: 11261060]

Schectman 1996 \{published data only\} . Schectman G, Wolff N, Byrd JC, Hiatt JG, Hartz A. Physician extenders for cost-effective management of hypercholesterolemia. Journal of General Internal Medicine. 1996; 11(5):277-86. MEDLINE: Medline 96338658. [PubMed: 8725976]

Scherwitz 1995 \{published data only\}. Scherwitz LW, Brusis OA, Kesten D, Safian PA, Hasper E, Berg A, et al. Life style changes in patients with myocardial infarct in the framework of intramural and ambulatory rehabilitation--results of a German pilot study. Zeitschrift fur Kardiologie. 1995; 84(3):216-21. [PubMed: 7732714]

Schwed 1999 \{published data only\} . Schwed A, Fallab CL, Burnier M, Waeber B, Kappenberger L, Burnand B, Darioli R. Electronic monitoring of compliance to lipid-lowering therapy in clinical practice. Journal of Clinical Pharmacology. 1999; 39(4):402-9. [PubMed: 10197299]

Senaratne 2001 \{published data only\} . Senaratne MP, Griffiths J, Mooney D, Kasza L, Macdonald K, Hare S. Effectiveness of a planned strategy using cardiac rehabilitation nurses for the management of dyslipidemia in patients with coronary artery disease. American Heart Journal. 2001; 142(6):975-81. [PubMed: 11717600]

Shaffer 1995 \{published data only\} . Shaffer JWL. Reducing low-density lipoprotein cholesterol levels in an ambulatory care system. Results of a multidisciplinary collaborative practice lipid clinic compared with traditional physician-based care. Archives of Internal Medicine. 1995; 155(21):2330-5. [PubMed: 7487258]

Shively 1991 \{published data only\} . Shively M, Fitzsimmons L, Verderber A. Research connections: treating hypercholesterolemia. Journal of Cardiovascular Nursing. 1991; 5(2):55-7. [PubMed: 1987334] 
Simpson 2001 \{published data only\} . Simpson SH, Johnson JA, Tsuyuki RT. Economic impact of community pharmacist intervention in cholesterol risk management: an evaluation of the study of cardiovascular risk intervention by pharmacists. Pharmacotherapy. 2001; 21(5):627-35.

MEDLINE: Medline 21247386. [PubMed: 11349751]

Tsuyuki 1999 \{published data only\} . Tsuyuki RT, Johnson JA, Teo KK, Ackman ML, Biggs RS, Cave A, et al. Study of Cardiovascular Risk Intervention by Pharmacists (SCRIP): a randomized trial design of the effect of a community pharmacist intervention program on serum cholesterol risk. Annals of Pharmacotherapy. 1999; 33(9):910-9. [PubMed: 10492489]

Tsuyuki 2002 \{published data only\} . Tsuyuki RT, Johnson JA, Teo KK, Simpson SH, Ackman ML, Biggs RS, et al. A randomized trial of the effect of community pharmacist intervention on cholesterol risk management: the Study of Cardiovascular Risk Intervention by Pharmacists (SCRIP). Archives of Internal Medicine. 2002; 162(10):1149-55. [PubMed: 12020186]

Tully 2000 \{published data only\} . Tully MP, Seston EM. Impact of pharmacists providing a prescription review and monitoring service in ambulatory care or community practice. Annals of Pharmacotherapy. 2000; 34(11):1320-31. [PubMed: 11098348]

Urquhart 1999 \{published data only\} . Urquhart J. Pharmacoeconomic consequences of variable patient compliance with prescribed drug regimens. Pharmacoeconomics. 1999; 15(3):217-28. [PubMed: 10537430]

Vale 2002 \{published data only\} . Vale MJ, Jelinek MV, Best JD, Santamaria JD. Coaching patients with coronary heart disease to achieve the target cholesterol: a method to bridge the gap between evidence-based medicine and the "real world"--randomized controlled trial. Journal of Clinical Epidemiology. 2002; 55(3):245-52. [PubMed: 11864795]

Velonakis 1999 \{published data only\} . Velonakis E, Sourtzi P, Komitopoulos N, Ioannides J, Varsamis E. A health promotion programme for the prevention of cardiovascular diseases in the elderly. International Journal of Health Promotion \& Education. 1999; 37(1):26-9.

Verges 1998 \{published data only\} . Verges BL, Patois-Verges B, Cohen M, Casillas JM. Comprehensive cardiac rehabilitation improves the control of dyslipidemia in secondary prevention. Journal of Cardiopulmonary Rehabilitation. 1998; 18(6):408-15. [PubMed: 9857272]

Wahlstrom 1995 \{published data only\} . Wahlstrom R, Tomson G, Diwan VK, Beermann B, Sterky G. Hyperlipidaemia in primary care - A randomized controlled trial on treatment information in Sweden: Design and methodology. Pharmacoepidemiology \& Drug Safety. 1995; 4(2):75-90.

Wei 2002 \{published data only . Wei L, Wang J, Thompson P, Wong S, Struthers AD, MacDonald TM. Adherence to statin treatment and readmission of patients after myocardial infarction: a six year follow up study. Heart (British Cardiac Society). 2002; 88(3):229-33. [PubMed: 12181210]

Wright 2002 \{published data only\} . Wright L. The specialist nurse in coronary heart disease prevention: Evidence for effectiveness. British Journal of Cardiology. 2002; 9(Suppl. 3):S15S19.

Zermansky 2002 \{published data only\} .Zermansky AG, Petty DR, Raynor DK, Lowe CJ, Freemantle N, Vail A. Clinical medication review by a pharmacist of patients on repeat prescriptions in general practice: A randomised controlled trial. Health Technology Assessment (Winchester, England). 2002; 6(20):76.

\section{References to ongoing studies}

De Klerk 2003 \{unpublished data only\}. Improved compliance and persistence with atorvastatin through a pharmacy -based intervention. Ongoing study not reported.

\section{Additional references}

4S 1994 . Scandinavian, Simvastatin; Survival Study Group. Randomised trial of cholesterol lowering in 4444 patients with coronary heart disease: the Scandinavian Simvastatin Survival Study (4S). Lancet. 1994; 344(8934):1383-9. [PubMed: 7968073] 
Alderson 2004 . Alderson P, Green S, Higgins JPT. Section 6 Assessment of study quality. Cochrane Reviewers' Handbook 4.2.2 [updated December 2003]. http://www.cochrane.org/resources/ handbook/hbook.htm

Assmann 2000 . Assmann SF, Pocock SJ, Enos LE, Kasten LE. Subgroup analysis and other (mis)uses of baseline data in clinical trials. Lancet. 2000; 355(9209):1064-9. [PubMed: 10744093]

Athyros 2002a . Athyros VG, Papageorgiou AA, Mercouris BR, Athyrou VV, Symeonidis AN, Basayannis EO, et al. Treatment with atorvastatin to the National Cholesterol Educational Program goal versus 'usual' care in secondary coronary heart disease prevention. The GREek Atorvastatin and Coronary-heart-disease Evaluation (GREACE) study. Current Medical Research \& Opinion. 2002; 18(4):220-8. [PubMed: 12201623]

ATP III . Expert Panel on Detection, Evaluation and Treatment of High Blood Cholesterol in Adults (ATP III). Third Report of the National Cholesterol Education Program (NCEP). http:// www.nhlbi.nih.gov/guidelines/cholesterol/atp3xsum.pdf

Avorn 1998 . Avorn J, Monette J, Lacour A, Bohn RL, Monane M, Mogun H, et al. Persistence of Use of Lipid-Lowering Medications. JAMA. 1998; 279(18):1458-62. [PubMed: 9600480]

Benner 2002 . Benner JS, Glynn RJ, Mogun H, Neumann PJ, Weinstein MC, Avorn J. Long-term persistence in use of statin therapy in elderly patients. JAMA. 2002; 288(4):455-61. [PubMed: 12132975]

Clarke 2002 . Clarke, M.; Oxman, AD., editors. The Cochrane Reviewers Handbook. 4.1.5.. Oxford: 2002. Assessment of study quality (updated April 2002); Section 6. Update Software

Dickersin 1994 . Dickersin K, Scherer R, Lefebvre C. Identifying relevant studies for systematic reviews. British Medical Journal. 1994; 309:1286-91. [PubMed: 7718048]

DOH 2000 . Department of Health. Coronary Heart Disease. National Service Framework. 2000 Chapter 2. [MEDLINE: 10].

Dolan 1985 . Dolan MP, Green LW, Persinger GS. Clinical trials of patient education for chronic conditions: A comparative meta-analysis of intervention types. Preventive Medicine. 1985; 14(6):753-81. [PubMed: 2418436]

Downs 1998 . Downs JR, Clearfield M, Weis S, Whitney E, Shapiro DR, Beere PA, et al. Primary prevention of acute coronary events with lovastatin in men and women with average cholesterol levels: results of AFCAPS/TexCAPS. Air Force/Texas Coronary Atherosclerosis Prevention Study. JAMA. 1998; 279(20):1615-22. [PubMed: 9613910]

Eriksson 1998 . Eriksson M, Hadell K, Holme I, Walldius G, Kjellstrom T. Compliance with and efficacy of treatment with pravastatin and cholestyramine: A randomized study on lipid-lowering in primary care. Journal of Internal Medicine. 1998; 243(5):373-80. [PubMed: 9651560]

Haddad 2000 . Haddad M, Inch C, Glazier RH, Wilkins AL, Urbshott G, Bayoumi A, et al. Patient support and education for promoting adherence to highly active antiretroviral therapy for HIV/ AIDS. The Cochrane Library. 2004; (2) Art. No.: CD001442. DOI: 10.1002/14651858.CD001442.pub2.

Haynes 2004 . Haynes RB, Mc Donald H, Garg AX, Montague P. Interventions for helping patients to follow prescriptions for medications. The Cochrane Library. 2004; (2)

Lefebvre 1996 . Lefebvre, C.; McDonald, S. Development of a sensitive search strategy for reports of randomized controlled trials in EMBASE; Paper presented at the Fourth International Cochrane Colloquium; Adelaide, Australia. 1996; Oct 20-24. 1996

Lewis 2003 . Lewis DK, Robinson J, Wilkinson E. Factors involved in deciding to start preventive treatment: qualitative study of clinicians' and lay people's attitudes. British Medical Journal. 2003; 327:841-5. [PubMed: 14551099]

LIPID 1998 . Long Term Intervention with Pravastatin in Ischaemic Disease (LIPID) study group. New England Journal of Medicine. Vol. 339. The Long-Term Intervention with Pravastatin in Ischaemic Disease (LIPID) Study Group; 1998. Prevention of cardiovascular events and death with pravastatin in patients with coronary heart disease and a broad range of initial cholesterol levels; p. 1349-57. 
Maenpaa 1987 . Maenpaa H, Manninen V, Heinonen OP. Comparison of the digoxin marker with capsule counting and compliance questionnaire methods for measuring compliance to medication in a clinical trial. European Heart Journal. 1987; 8(Suppl 1):39-43. [PubMed: 3322829]

Maenpaa 1991 . Maenpaa H, Heinonen OP, Manninen V. Medication compliance and serum lipid changes in the Helsinki Heart Study. British Journal of Clinical Pharmacology. 1991; 32(4):409_ 15. [PubMed: 1958432]

Moher 1999 . Moher D, Cook DJ, Eastwood S, Olkin I, Rennie D, Stroup D for the QUORUM group. Improving the quality of reporting of meta-analyses of randomised controlled trials: the QUORUM statement. Lancet. 1999; 354:1896-1900. [PubMed: 10584742]

MRC/BHF 2002 . Heart Protection Study Collaborative Group. MRC/BHF Protection Study of cholesterol lowering with simvastatin in 20536 high-risk individuals: a randomised placebocontrolled trial. Lancet. 2002; 360:7-22. [PubMed: 12114036]

Mullen 1997 . Mullen PD. Compliance becomes concordance. British Medical Journal. 1997; 314:691-2. [PubMed: 9116538]

Primatesta 2000 . Primatesta P, Poulter NR. Lipid concentrations and the use of lipid lowering drugs: evidence from a national cross sectional survey. BMJ. 2000; 321(7272):1322-5. [PubMed: 11090516]

Roter 1998 . Roter DL, Hall JA, Merisca R, Nordstrom B, Cretin D, Svarstad B. Effectiveness of interventions to improve patient compliance: a meta-analysis. Medical Care. 1998; 36(8):113861. [PubMed: 9708588]

RPS 1997 . Royal Pharmaceutical Society of Great Britain. From compliance to concordance: towards shared goals in medicine taking. RPS; London: 1997.

Sackett 1976 . Sackett, DL.; Haynes, RB. Compliance with therapeutic regimens. John Hopkins University Press; Baltimore: 1976.

Sacks 1996 . Sacks FM, Pfeffer MA, Moye LA, Rouleau JL, Rutherford JD, Cole TG, et al. The effect of pravastatin on coronary events after myocardial infarction in patients with average cholesterol levels. Cholesterol and Recurrent Events Trial investigators. New England Journal of Medicine. 1996; 335(14):1001-9. [PubMed: 8801446]

Schroeder 2004a . Schroder K, Fahey T, Ebrahim S. Adherence to long-term therapies. Journal of Clinical Epidemiology. 2004; 57(1):2-3. [PubMed: 15019004]

Schroeder 2004b . Schroeder K, Fahey T, Ebrahim S. Interventions for improving adherence to treatment in patients with high bloos pressure in ambulatory settings. Cochrane Library. 2004; (2)

Shepherd 1995 . Shepherd J, Cobbe SM, Ford I, Isles CG, Lorimer AR, MacFarlane PW, et al. Prevention of coronary heart disease with pravastatin in men with hypercholesterolemia. West of Scotland Coronary Prevention Study Group. New England Journal of Medicine. 1995; 333(20): 1301-7. [PubMed: 7566020]

SIGN 1999 . Scottish Intercollegiate Guidelines Network (SIGN). Lipids and primary prevention of coronary heart disease. Sep. 19999 Available: http://www.sign.sign.ac.uk

Stata . College Station,TX: Stata Corporation. Stata Corp. Stata Statistical Software: Release 8.0. Stata Corporation; College Station,TX: 2002.

Straka 1997 . Straka RJ, Fish JT, Benson SR, Suh JT. Patient self-reporting of compliance does not correspond with electronic monitoring: An evaluation using isosorbide dinitrate as a model drug. Pharmacotherapy. 1997; 17(1):126-32. [PubMed: 9017773]

Tsuyuki 2001 . Tsuyuki RT, Bungard TJ. Poor adherence with hypolipidemic drugs: a lost opportunity. Pharmacotherapy. 2001; 21(5):576-82. [PubMed: 11349746]

Urquhart 1994 . Urquhart J. Role of patient compliance in clinical pharmacokinetics: A review of recent research. Clinical Pharmacokinetics. 1994; 27(3):202-15. [PubMed: 7988102]

Vermeire 2001 . Vermeire E, Hearnshaw H, Van Royen P, Denekens J. Patient adherence to treatment: three decades of research. A comprehensive review. Journal of Clinical Pharmacy \& Therapeutics. 2001; 26(5):331-42. [PubMed: 11679023]

WHO 2002 . WHO. Cardiovascular Death and Disability can be reduced more than 50 percent. Oct 17. 2002 http://www.who.int/mediacentre/releases/pr83/en/MEDLINE: 18 
WHO Report 2002 . WHO. The World Health Report 2002. 2002. http://www.who.int/whr/2002/en/ MEDLINE: 19 


\section{PLAIN LANGUAGE SUMMARY}

People at risk or suffering from cardiovascular disease need to be encouraged to take drugs which decrease blood lipids (lipid lowering medication/cholesterol lowering medication)

Lipid lowering medication has been shown to be very effective in the prevention of heart attack and stroke. People can find it difficult to take their medicines as prescribed, and this is thought to be an important factor in treatment failure. Doctors are keen for patients to take their medication at the right dosage and long term. This review of trials reports interventions to improve patients' drug taking behaviour (medication adherence). It shows that so far no specific type of intervention has been found to be particularly successful. 